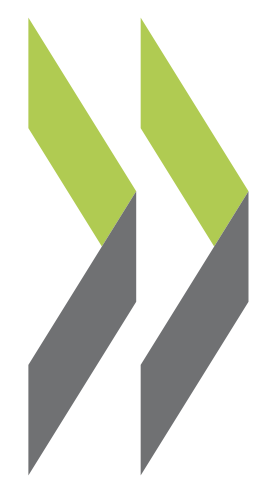

\title{
Taxation, Business Environment and FDI Location in OECD Countries
}

Dana Hajkova, Giuseppe Nicoletti, Laura Vartia, Kwang-Yeol Yoo 
Organisation de Coopération et de Développement Economiques

Organisation for Economic Co-operation and Development

24-Jul-2006

ECONOMICS DEPARTMENT

English - Or. English

TAXATION, BUSINESS ENVIRONMENT AND FDI LOCATION IN OECD COUNTRIES

ECONOMICS DEPARTMENT WORKING PAPERS No. 502

By

Dana Hajkova, Giuseppe Nicoletti, Laura Vartia and Kwang-Yeol Yoo

All Economics Department Working Papers are available through OECD's internet web site at www.oecd.org/eco/working_papers.

JT03212208

Document complet disponible sur OLIS dans son format d'origine

Complete document available on OLIS in its original format 
ECO/WKP(2006)30 
ECO/WKP(2006)30

\section{ABSTRACT/RESUME \\ Taxation, Business Environment and FDI Location in OECD Countries}

This paper assesses the importance of taxation on foreign direct investment contributing to the literature in two ways. First, it relates bilateral FDI among OECD countries over the 1990s to a new set of estimates of corporate tax wedges that include many relevant aspects of FDI taxation. Second, it controls for a large set of additional policy and non-policy factors that may affect the attractiveness of a country for foreign investors. Furthermore, the empirical approach is novel in that it focuses on a semi-parametric estimation methodology that accounts for a number of unobserved effects possibly impinging on the choice of investment location by multinational enterprises. Consistent with previous findings, the estimation results suggest that corporate taxation has a non-negligible impact on FDI location choices. However, the results suggest that focusing only on taxation in home and host countries and omitting other policies (such as border policies and labour and product market settings) may lead to a serious overestimation of tax elasticities and their relevance for policy.

JEL classification: F21, F23, H25, C23, L50

Key words: Foreign direct investment, corporate taxation, regulation, panel data

$* * * * *$

\section{Fiscalité, environnement des entreprises et localisation des IDE dans les pays OCDE}

Cette étude évalue l'importance des politiques fiscales pour les investissements directs étrangers (IDE). Il contribue a littérature de deux façons: d'une part, l'étude établit un rapport entre les IDE bilatéraux dans les pays de l'OCDE pendant les années 90 et un nouvel ensemble d'indicateurs de taux effectifs d'imposition des sociétés couvrant plusieurs aspects de la taxation sur les IDE. D'autre part, il contrôle pour un ensemble des politiques économiques et autres facteurs susceptibles d'influencer l'attractivité d'un territoire pour les investisseurs étrangers. En outre, l'approche empirique est originale dans la mesure où elle utilise une méthodologie d'estimation semi-parametrique qui tient compte des effets inobservables affectant le choix de localisation des entreprises multinationales. En ligne avec les conclusions de la littérature, les résultats indiquent que l'imposition des sociétés a des incidences non-négligeables sur les choix de localisation des IDE. Cependant, les résultats indiquent qu'il est possible de sérieusement surestimer les élasticités par rapport aux taxes et leur importance politique en se concentrant seulement sur les impôts dans les pays d'origine et d'accueil des investissements, sans prendre en compte un certain nombre de politiques (telles que les obstacles frontaliers et le fonctionnement du marché du travail et des produits).

Classification JEL: F21, F23, H25, C23, L50

Mots-Clés: Investissements directs étrangers, fiscalité des entreprises, données de panel

\section{Copyright OECD, 2006}

Application for permission to reproduce or translate all, or part of, this material should be made to: Head of Publications, OECD, 2, rue André-Pascal, 75775 Cedex 16, France. 
TABLE OF CONTENTS

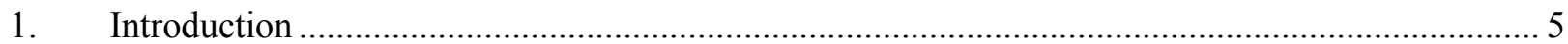

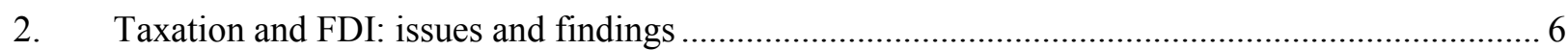

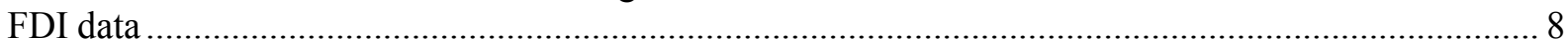

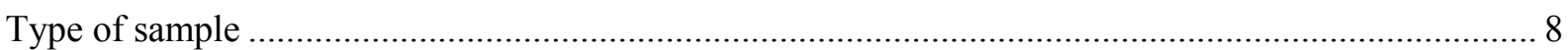

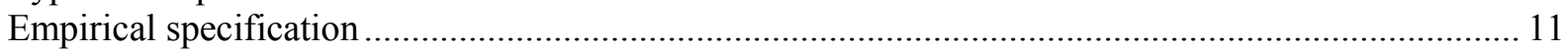

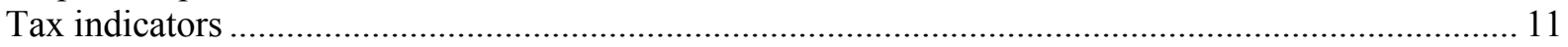

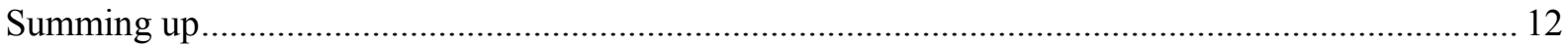

3. Data, model specification and empirical methodology ....................................................... 12

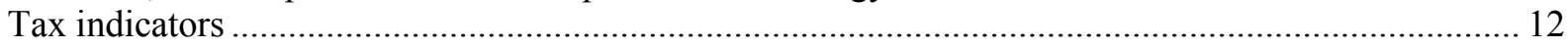

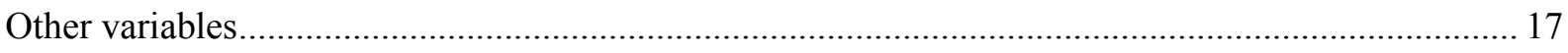

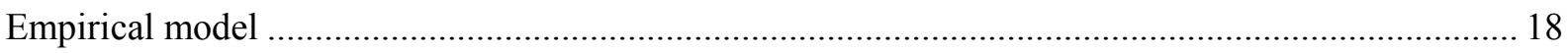

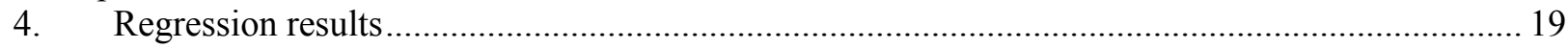

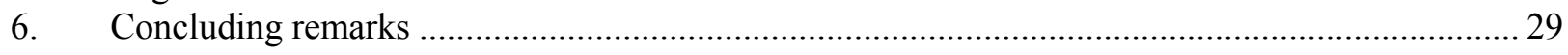

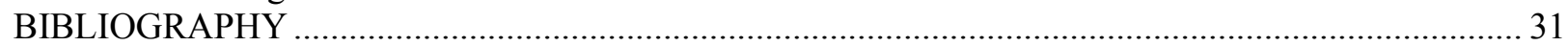

Tables and Figures

Tables

1. Comparison of "typical" semi-elasticities and elasticities

2. Summary of results from panel data studies

3. $\quad$ The effect of the AETR on FDI stocks - years 1996-1999

4. The effect of METRs on FDI stocks - years 1991-1999

5. The effect of corporate tax rates on FDI stocks - 1991-1999

6. The effect of the METR and AETR on FDI stocks ${ }^{\mathrm{a}}$

7. Summary of estimated tax elasticities in different models

\section{Figures}

1. The effective tax rates on inward and outward FDI ${ }^{1}$

2. Variation of the effective rates on inward FDI applied by host country, $2001^{1}$

3. Contributions of policy factors to the deviations in $\mathrm{FDI}^{1}$ 
ECO/WKP(2006)30

\title{
TAXATION, BUSINESS ENVIRONMENT AND FDI LOCATION IN OECD COUNTRIES
}

\author{
Dana Hajkova, Giuseppe Nicoletti, Laura Vartia and Kwang-Yeol Yoo ${ }^{1}$
}

\section{Introduction}

1. How important are corporate taxation regimes faced by multinational enterprises (MNE) for their location choices? To what extent does foreign direct investment (FDI) respond to international differences in such regimes? Over the past decade, interest in these issues has been growing in parallel with the increasing mobility of capital and internationalisation of businesses. Standard models of the MNE predict that corporate taxation can influence FDI by creating a wedge between the pre- and post-tax returns on investment. The relevant tax wedge, however, depends on whether MNE's investment is incremental or involves the creation of entirely new plants. Moreover, the size of the wedge depends on the whole set of tax policies implemented by the home and host countries - including, for instance, exemption or credit regimes for foreign source income, withholding taxes on repatriated profits or dividends and FDI specific tax incentives. Recent studies have also shown that MNE may de facto close the wedge implied by international corporate taxation by implementing "triangular" strategies that exploit cross-country differences in tax policies to defer or avoid tax obligations (Grubert, 2004; Altshuler and Grubert, 2003). Given the uncertainty surrounding the relevant tax wedges and the response of MNE to them, a large number of studies have explored the issue empirically. ${ }^{2}$

2. While empirical studies generally find that FDI choices are significantly affected by various measures of corporate taxation, many of them focus on just a few countries (often bilateral relations between the United States and its partners), ${ }^{3}$ use tax variables that do not cover important dimensions of bilateral tax regimes (such as the tax treatment of foreign income) and, most importantly, omit to account explicitly for other policies that are likely to be relevant for MNE's choices - such as border barriers and the domestic business environment. Omission of these variables is likely to bias the estimated tax elasticities because taxation regimes and other domestic policies are often correlated over time and across countries.

1. Giuseppe Nicoletti and Laura Vartia are economists at the OECD Economics Department. Dana Hajkova is an economist with the Czech National Bank and Kwang-Yeol Yoo with the Korean Ministry of Finance and Economy and they were working at the OECD Economics Department when a previous version of this paper was written. The views expressed are those of the authors and do not necessarily reflect those of the OECD. The authors would like to thank Mike Feiner, Christopher Heady, Andreas Woergoetter and other colleagues in the Economics Department and Centre for Tax Policy and Administration for valuable comments and suggestions.

2. Hines (1999) and Mooij and Everdeen (2001 and 2005) provide comprehensive overviews of these studies.

3. Devereux and Freeman (1995), Hines (1998), Mayer and Mucchielle (1999), Gropp and Kostial (2000) and Bénassy-Quéré et al. (2003 and 2005) are recent exceptions. 
3. This paper looks at the effects of corporate taxation on bilateral FDI stocks in 28 investing countries and their partners, focusing on the OECD area over the 1990s, contributing to previous panel data analyses of the tax/FDI nexus in two main ways. First, the paper relates bilateral FDI with a new set of estimates of tax wedges that include many relevant aspects of FDI-specific taxation. These estimates are based on tax codes and provide marginal effective tax rates (METR) and average effective tax rates (AETR) on FDI for each OECD country pair. Second, the paper controls for a large set of additional factors that may affect the attractiveness of a country for international investors. These include openness to foreign trade and investment, the cost and regulation of labour, and policies that affect the degree of domestic market competition. Both tax and other policy indicators have a time-series dimension, covering changes that occurred over the sample period. This would seem to be the first analysis of the tax and FDI issue that embodies such a large set of countries and policies over a decade during which many changes were observed both in taxation and other policy regimes. Furthermore, variation over time and across country pairs is used to identify better the elasticities of FDI to corporate taxation arrangements.

4. This empirical approach is novel also in other respects. The empirical analysis is implemented in the context of Markusen's (2002) "unified approach" to the analysis of MNE cross-border investment, in which gravity, comparative advantage and scale factors may all drive FDI location choices. This accounts for both market access (so-called "horizontal") and production fragmentation ("vertical") motives for creating or extending foreign affiliates in host countries. Moreover, following Erkel-Rousse and Mirza (2002), the paper is based on a semi-parametric estimation approach that allows to control for a number of unobserved effects (such as cultural or historical linkages between country pairs) possibly impinging on the choice of investment location by MNE.

5. Consistent with previous findings, the regressions suggest that corporate taxation has a significant impact on FDI location choices, and that forward-looking measures based on tax codes including bilateral arrangements and features of foreign income taxation - capture this impact more effectively than simple statutory rates. In keeping with the literature, the largest impact is recorded for AETR, which account for taxation in infra-marginal investment, while exemption or credit systems do not significantly affect the estimated tax elasticities. Moving to an exemption system tends, however, to increase FDI stocks.

6. The results indicate that omission of other policies that shape the business environment of host countries may lead to serious upward bias in tax elasticity estimates. Moving from a simple model specification including only tax policies to a wider one covering also other factors and policies affecting rates of return on FDI significantly lowers the estimated tax elasticities. As a result, the elasticity estimates are on the low side of the range covered by recent surveys of the empirical literature. Moreover, the impact of tax regimes on bilateral FDI appears to be quantitatively limited. On the whole, taxation would seem to be a relatively minor factor affecting the location choices of MNE as compared to policies affecting the ease of entry for foreign firms, their labour costs and the functioning of product markets in the host country. These results appear to be robust to changes in model specification and estimation methods as well as to accounting for the possibility of FDI diversion from third countries.

7. The remainder of the paper is organised as follows. The next section reviews the tax elasticities found in previous studies. Section 3 describes the data and the empirical methodology, with a special focus on the indicators used to proxy for FDI taxation and other policies. Section 4 presents the regression results. The final section discusses some policy implications and directions for future research.

\section{Taxation and FDI: issues and findings}

8. Most theoretical and empirical models of MNE behaviour or FDI implicitly or explicitly draw upon the so-called OLI approach pioneered by Dunning (1977, 1981), which relates cross-border 
investment to three main motives - ownership, location, and internalisation. In principle, taxation can affect each of them. For example, taxation may influence the incentive of MNE to establish a foreign subsidiary by increasing or reducing the advantage associated with ownership (e.g., tax treatment of royalties, dividend repatriation). At the same time, the host-country corporate tax rate contributes to determine the comparative location advantage that it can offer to international investors relative to other destination countries. More generally, corporate taxation and the tax treatment of foreign corporate income are likely to affect the wedge between the pre-tax and post-tax rates of return on FDI. This will affect the extent to which MNE can enjoy internalisation advantages relative to the alternatives of exporting or licensing their products in host countries.

9. Changes in tax regimes over time and/or cross-country differences in the tax treatment of foreign source income can influence both the evolution and the cross-country distribution of FDI. These effects can, however, be limited by the ability of MNE to design business and/or fiscal strategies that minimise the tax burden on their foreign affiliates, taking advantage of the possibility to arbitrage among different tax regimes (so-called "tax planning" strategies). Moreover, taxation is only one among the many structural and policy-related factors that determine the attractiveness of a country for international investors, a point that will be elaborated further below. The actual impact of taxation on FDI is therefore mostly an empirical issue.

10. A sizeable literature has been devoted to measuring the response of FDI to taxation since the mid-1980s. In their thorough review, De Mooij and Ederveen (2005) provide a useful analysis of these empirical studies that differ mainly by the type of FDI data, the type of sample, the type of tax indicators and the specification of the empirical models. ${ }^{4}$ Table 1 reproduces the "typical" tax elasticities (and semielasticities) that they derive in their meta-analysis of studies that use different data and empirical approaches. A brief summary of their main findings concerning the above four headings follows.

4. Previous surveys include Hines (1997, 1999). 
Table 1. Comparison of "typical" semi-elasticities and elasticities

\begin{tabular}{|c|c|c|c|c|c|c|c|c|}
\hline \multicolumn{9}{|c|}{$\begin{array}{c}\text { Panel A Average semi-elasticities } \\
\end{array}$} \\
\hline & Country STR ${ }^{b}$ & State & $\mathrm{STR}^{\mathrm{C}}$ & METR $^{d}$ & AETR $^{\mathrm{e}}$ & Micro ATR $^{\mathrm{e}}$ & Macro ATR ${ }^{g}$ & Mean \\
\hline Time Series & -0.79 & & -6.74 & -2.22 & -4.63 & -0.77 & -2.97 & -3.02 \\
\hline Discrete choice & 2.31 & & -3.64 & 0.88 & -1.54 & 2.33 & 0.13 & 0.08 \\
\hline Panel data & -1.92 & & -7.87 & -3.35 & -5.77 & -1.9 & -4.1 & -4.15 \\
\hline Cross section & -7.81 & & -13.75 & -9.24 & -11.65 & -7.79 & -9.99 & -10.04 \\
\hline Mean & -2.05 & & -8 & -3.48 & -5.9 & -2.03 & -4.23 & -4.28 \\
\hline \multicolumn{9}{|c|}{ Panel B Average elasticities } \\
\hline & Country STR ${ }^{b}$ & State & $\mathrm{STR}^{\mathrm{C}}$ & METR $^{d}$ & $\mathrm{AETR}^{\mathrm{e}}$ & Micro ATR ${ }^{f}$ & Macro ATR ${ }^{g}$ & Mean \\
\hline Time Series & -1.13 & & -1.09 & -1.11 & -1.79 & -1.33 & -1.33 & -1.29 \\
\hline Discrete choice & -0.19 & & -0.15 & -0.17 & -0.85 & -0.39 & -0.39 & -0.36 \\
\hline Panel data & -0.65 & & -0.61 & -0.63 & -1.31 & -0.85 & -0.85 & -0.82 \\
\hline Cross section & -1.81 & & -1.77 & -1.79 & -2.47 & -2.1 & -2.1 & -1.98 \\
\hline Mean & -0.95 & & -0.91 & -0.93 & -1.61 & -1.15 & -1.15 & -1.11 \\
\hline
\end{tabular}

a) Elasticities are obtained from a meta analysis by de Mooij and Ederveen (2005)

b) Country statutory tax rate

c) State statutory tax rate

d) Marginal effective tax rate

e) Average effective tax rate

f) Average tax rate computed using micro-level data

g) Average tax rate computed using micro-level data

\section{FDI data}

11. FDI data are obviously crucial for the estimated tax elasticities. They can be based on cross-border financial flows (or stocks), real activity of foreign affiliates (e.g., property, plant and equipment) and count data on the location of subsidiaries. Data on real activity are considered to be more reliable than both count data and financial data for proxying the amount of real capital invested. Count data cannot account for the possible impact of taxation on the amount of investment in foreign affiliates, while financial data mix real investments with mergers and acquisitions that are likely to respond quite differently to taxation. ${ }^{5}$ Existing studies show that both tend to underestimate tax elasticities relative to real activity data. Nonetheless, financial flows are the only widely available data for cross-country (or cross-industry) and time-series analyses of bilateral FDI. Moreover, the available evidence suggests that the potential downward bias on elasticity estimates implied by these data is substantially smaller than the one implied by the use of count data. ${ }^{6}$

\section{Type of sample}

12. Sample types encompass analyses that are purely time-series, purely cross sectional and panel (either industry/time or bilateral/time). The majority of purely time-series and cross-sectional analyses focus on the United States and look at either aggregate FDI or the distribution of bilateral FDI from the United States to foreign countries or from foreign countries to the United States, in some cases

5. Moreover, financial flows may be geographically biased due to MNE's use of strategically-located holdings to intermediate their real investments.

6. In the meta-regressions of de Mooij and Ederveen (2005), which control for other sources of bias, "typical" elasticity estimates based on count data are significantly lower than those estimated using total financial FDI data. 
distinguishing among destination states. A few similar studies have also looked at investments of German MNE in the EU. All these analyses have been made using data on real activity or the number of locations of subsidiaries. By contrast, panel analyses generally use financial flows (or stock) data that are either aggregate (but broken down by industry) or bilateral (often for relatively small subsets of OECD countries). Meta-analysis results suggest that the "typical" elasticities estimated using panel data are close to the mean elasticity values obtained from a survey of studies covering all data sources and sample types. Table 2, also drawn from de Mooij and Ederveen (2005), shows however that tax elasticity estimates obtained from panel data analyses vary widely across individual studies depending on precise model specifications. 
Table 2. Summary of results from panel data

\begin{tabular}{|c|c|c|c|c|c|c|c|c|}
\hline & \multicolumn{3}{|c|}{ Semi-elasticity } & \multicolumn{3}{|c|}{ Elasticity } & \multirow[t]{2}{*}{ No. obs } & \multirow[t]{2}{*}{ No. sign } \\
\hline & Mean & Median & Std. dev. & Mean & Median & Std. dev. & & \\
\hline Swenson, 1994 & 1.26 & 2.72 & 4.25 & 0.36 & 0.76 & 1 & 10 & 6 \\
\hline Jun, 1994 & -0.5 & -1.26 & 3.17 & -0.15 & -0.35 & 1.08 & 10 & 1 \\
\hline Devereux \& Freeman, 1995 & -1.56 & -1.55 & 0.12 & -0.39 & -0.39 & 0.03 & 4 & 1 \\
\hline Pain \& Young, 1996 & -1.51 & -1.38 & 1.22 & -0.75 & -0.68 & 0.59 & 6 & 3 \\
\hline Shang-Jin Wei, 1997 & -5.2 & -5 & 0.64 & -1.53 & -1.47 & 0.19 & 5 & 5 \\
\hline Billington, 1999 & -0.1 & -0.1 & 0.01 & -0.04 & -0.04 & 0.01 & 2 & 2 \\
\hline Gorter \& Parikh, 2000 & -4.56 & -4.64 & 4.25 & -1.3 & -1.33 & 1.22 & 15 & 10 \\
\hline Broekman \& Vliet, 2000 & -3.35 & -3.51 & 0.77 & -1 & -1.05 & 0.23 & 3 & 3 \\
\hline Benassy-Quere et al., 2001 & -5.03 & -5.01 & 3.03 & -0.43 & -0.42 & 0.24 & 4 & 3 \\
\hline Buttner, 2002 & -1.52 & -1.59 & 0.58 & -0.44 & -0.39 & 0.22 & 23 & 12 \\
\hline Benassy-Quere et al., 2003 & -5.37 & -4.22 & 3.21 & -1.59 & -1.25 & 0.95 & 19 & 19 \\
\hline Desai, et al., 2004 & -0.64 & -0.64 & 0.02 & -0.19 & -0.19 & 0.01 & 2 & 2 \\
\hline Stoewhase, 2005 & -5.26 & -4.3 & 2.71 & -1.53 & -1.27 & 0.79 & 14 & 11 \\
\hline All & -2.94 & -2.51 & 3.51 & -0.84 & -0.67 & 1 & 117 & 78 \\
\hline
\end{tabular}

Source: Mooij and Ederveen (2005). 
ECO/WKP(2006)30

\section{Empirical specification}

13. Model specification issues involve the choice of both non-policy factors and policy factors (other than tax rates) that are included in the regression models. Concerning the former, recent analyses often tend to account for factors related to gravity, factor proportions and firm and/or plant-specific economies of scale; other controls include proxies for agglomeration and openness. Few studies, however, estimate specifications covering all these factors, as would be suggested by Markusen's (2002) "knowledge capital" or "unified" approach that formalises and extends the earlier OLI framework. Turning to policy factors, a widely debated empirical issue is whether home countries' different tax treatment concerning foreignsource income (exemption or credit systems) affects investors' responses to changes in host countries' taxation. ${ }^{7}$ Most studies, however, do not find significant differences in the elasticity of FDI to host-country taxation under alternative foreign source income taxation regimes. Thus, the distinction between credit and exemption countries may not be important in practice, due among other things to excess foreign credit, tax deferral and other tax planning strategies of MNE.

14. Inclusion of policy influences other than tax rates or bilateral tax agreements is much less common. Yet, the range of policy controls accounted for in regressions may have an important bearing on the estimated tax elasticities, due to potential omitted-variable bias. This is of course particularly important for policies that are likely to be correlated with the FDI taxation variable, such as border barriers, labour income taxation and product market regulation. The meta-analysis of de Mooij and Ederveen (2005) shows for instance that omission of openness factors can artificially increase tax elasticity estimates.

\section{Tax indicators}

15. A major unresolved issue in this strand of research is the choice of the best indicator for measuring the tax burden on FDI. Three main measures have been proposed: the statutory corporate tax rate in the host country; the average tax rate computed from tax revenue data; and the effective tax rate based on host and home country tax codes, bilateral arrangements concerning taxation of foreign income and economic assumptions (e.g., about the firm's typical financing and asset structure). Average tax rates can be computed using either macro data on corporate tax revenues or firm-level data on corporate tax payments, while effective tax rates can refer to either marginal or infra-marginal foreign investments. (See below for more details).

16. Apart from the degree of detail contained in these tax measures, they differ mainly in that those based on tax codes are "ex ante" or "forward looking", while those based on tax payments are "ex post". From an empirical point of view, "ex post" measures have the advantage of reflecting the actual impact of tax codes on the FDI tax wedge after MNE have implemented tax planning strategies to minimise the tax burden. However, they are also likely to reflect other factors, possibly unrelated to taxes (e.g., economic conditions). Moreover, they are also likely to be endogenous to the amount and the location of FDI itself. Alternative, "forward looking", measures have opposite properties: they are truly exogenous and identify mostly tax influences, but they may omit important features of the tax system and are unable to account for

7. A multinational residing in a credit-system country could in principle offset the increase in the host-country tax burden and leave its net tax burden unaffected by claiming foreign tax credits in the home country, while a multinational residing in an exemption-system country would not be able to avoid the rise in the host-country tax burden, implying a one-to-one rise in the overall tax burden. 
the possible effect of MNE tax planning strategies. ${ }^{8}$ Given the various factors at work, the potential bias on tax elasticity estimates implied by the use of these indicators is unclear a priori. Available evidence suggests that, independent of the FDI data and sample type used, estimated elasticities tend to be higher for average effective tax rates on infra-marginal investments (AETR) and macro-based average tax rates than for statutory tax rates, effective tax rates on marginal investments (METR) and micro-based average tax rates measures (Table 1).

\section{Summing up}

17. The results of previous studies provide insights that have several useful implications for the estimation strategy used in this paper. First, there is a consensus that data on real activity of foreign affiliates is ideally the most appropriate to gauge the effects of taxation on FDI. However, such data simply do not exist on a bilateral basis for a sufficiently large set of country pairs and periods. Moreover, the bias implied by the use of more widely available data on financial flows does not seem to be substantial. Second, within the spectrum of empirical approaches used in this kind of analysis, panel data studies seem to provide tax elasticities that are in the median range of available estimates. Third, from the point of view of obtaining unbiased estimates of tax elasticities, use of "forward looking" measures would appear to be safer because they reflect only tax factors and avoid the potential endogeneity problems of other measures. The inherent limitations of these measures suggest however to experiment also with other tax indicators. Finally, to obtain unbiased elasticity estimates, it is crucial to control not only for gravity and other factors but also for other policies that influence comparative location advantages by shaping after-tax rates of return on FDI and the more general business environment in which foreign affiliates operate.

\section{Data, model specification and empirical methodology}

\section{Tax indicators}

\section{The choice of METR and AETR}

18. As mentioned earlier, the two most common forward-looking bilateral tax burden indicators for FDI are the marginal effective tax rate (METR), and the average effective tax rate (AETR). These indicators measure the wedge between the pre-tax rate of return on investment earned by a company and the post-tax rate of return earned by its foreign parent, taking into account three dimensions of tax policies: the domestic corporate tax systems of home and host countries; the taxation of cross-border flows of income; and the interaction of tax systems of home and host countries. The METR applies to a marginal investment project that earns the minimum required rate of return after tax, whereas the AETR applies to an infra-marginal investment project that earns some economic rent, i.e. a project that earns after-tax pure profits. ${ }^{9}$

19. This paper uses recent estimates of these forward-looking indicators by Yoo (2003), who extended previous measures computed by OECD (1991) and the European Commission (2001). Yoo (2003) constructed METR and AETR for 1996 and 2001, and then used detailed information on tax

8. However, an additional advantage of these measures is that they can be used to simulate the effects of changes in single elements of tax regimes on FDI tax wedges, which is clearly impossible with "ex post" measures.

9. The METR was originally constructed by King and Fullerton (1984) and OECD (1991) for domestic and cross-border investment respectively. The AETR was developed by Devereux and Griffith (1999) and extended by the European Commission (2001) for cross-country comparisons of tax burdens on FDI. The construction of these indicators also incorporates a number of assumptions concerning the financing and asset structure of firms, asset-specific depreciation rates and inflation rates. 
reforms in individual OECD countries in various years to create time-series that change with the evolution of tax codes and bilateral or multilateral agreements. The two measures cover the 1991-2000 and 19962000 periods, respectively. ${ }^{10}$ As noted by Devereux and Griffith (2002), the AETR tends to be a better measure of the tax burden on FDI than the METR, because the AETR is relevant for decisions regarding lumpy investment, investment in the presence of imperfect competition, or for location decisions of MNE, which are the most common drivers of FDI. ${ }^{11}$ However, both measures are used to test the robustness of the results and also because a longer time-series is available for the METR.

20. It should also be reminded that these tax indicators do not take into account the possibility of a multinational to reallocate taxable income across different countries with a view to minimising its tax burden. International investors have access to alternative methods of financing FDI, arranging transactions between related parties located in different countries and changing the timing of repatriation of income to a parent company. ${ }^{12}$ To the extent that tax-planning by MNE reduces the tax wedges across host countries, the estimated tax indicators will tend to overestimate the cross-country difference in tax burdens. Moreover, these indicators do not incorporate fiscal incentives to foreign investment that are specific to certain regions or spending categories (such as R\&D or spending by SMEs). This can be another source of overestimation of the actual tax burden on FDI, especially in countries where entitlements to these incentives are widespread. Finally, the tax burden indicators are based on economic assumptions that are tailored to manufacturing, though a large and increasing share of FDI actually concerns non-manufacturing industries.

21. Nonetheless, these forward-looking indicators are preferred over the measures of the average tax rate (ATR) for several reasons. The ATR is calculated as aggregate taxes paid to the host country relative to the pre-tax earning and profits earned in the host country, both of which are available from tax return or accounting data. While the micro-level ATR accounts to some extent for MNE's "tax-planning" activities, recent evidence indicates that various tax-reducing alternatives to dividend repatriation, such as royalty payments to the parent and "triangular" or "multiple-tier" transactions between the parent and related

10. See Yoo (2003) for a detailed methodology and a description of the tax data used to estimate the METR and AETR.

11. A common reason for an MNE to create a foreign affiliate is to earn an economic rent by exploiting some firm-specific advantage (Markusen, 2002). Due to economies of scale in production, it will choose to build one plant among alternative locations.

12. Numerous studies have pointed out that the financial incentives of the MNEs to shift profits from one host country to the other are large. For example, Weichenrieder (1996) and Grubert (1998) confirmed a frequent reliance on intra-company loans for financing foreign affiliates in high corporate tax countries in order to exploit a favourable tax treatment for debt-financing. The phenomenon that firms manipulate prices used in intra-firm transactions with a view to reducing total tax liabilities has been confirmed by Grubert and Mutti (1991), Hines and Rice (1994), Harris (1993), Rousslang (1997) and Clausing (1998). Hines and Hubbard (1990) showed that multinationals also adjust the timing of their dividend repatriations from foreign subsidiaries. Recently Desai, Foley and Hines (2002), after reviewing affiliate-level data on the behaviour of US companies, suggested that the previous US evidence on the impact of taxation may underestimate the effect of taxation on the behaviour of multinationals. This was based on their empirical finding that the investment pattern of indirectly-owned affiliates of US multinationals was considerably more sensitive to local tax rates than was the investment pattern of directly-owned foreign affiliates. At the same time, efforts have been made to curb aggressive tax planning activities of MNE - such as the practice of allocating taxable profits to low-tax countries by manipulating prices in intra-firm transactions (transferpricing) and the practice of allocating company debt and the associated reduction for interest payments to subsidiaries in high-tax countries (thin capitalisation). In addition, many countries also responded to these issues by formulating very complex tax codes. Those include deferral of taxes on foreign-source income, apportionment rules of a parent's expenses, and special rules on foreign sales corporations. See Gresik (2001) for details. 
foreign affiliates, cannot be captured in simple ATR measures. ${ }^{13}$ In addition, the ATR reflects a wide range of investments of varying age, duration, asset composition and financing sources by construction. Moreover, international comparisons based on the ATR are made difficult by differences in accounting definitions and the timing of tax payments.

\section{Trends in METR and AETR}

22. There has been a significant variation in the effective tax rates on FDI over the 1990s, reflecting tax reforms in many OECD countries. When measured by the METR on inward FDI (i.e., the EMTR faced in each host country by a foreign investor from the average OECD country), the tax burden on average fell by 8 percentage points (Figure 1, panel A). The AETR followed a similar pattern over the second half of the past decade (Figure 1, panel B). Despite this generalised trend decline, a large variation in the tax burden faced by the average investor across host countries still remains (Figure 2) partly due to the crosscountry differences in withholding tax rates on cross-border flows of dividends and interest income vis-àvis partner countries, and the interaction of home and host countries' tax systems. For example, the difference between the maximum AETR and the minimum AETR in a given host country ranged from 9 to 31 percentage points in OECD countries in 2001 (Figure 2, panel B).

13. See, for example, Grubert (1998), Grubert and Mutti (1991), and Altshuler and Grubert (2002). 


\section{Figure 1. The effective tax rates on inward and outward FDI ${ }^{1}$}

Panel A. Effective marginal tax rates on inward $\mathrm{FDI}^{2}$

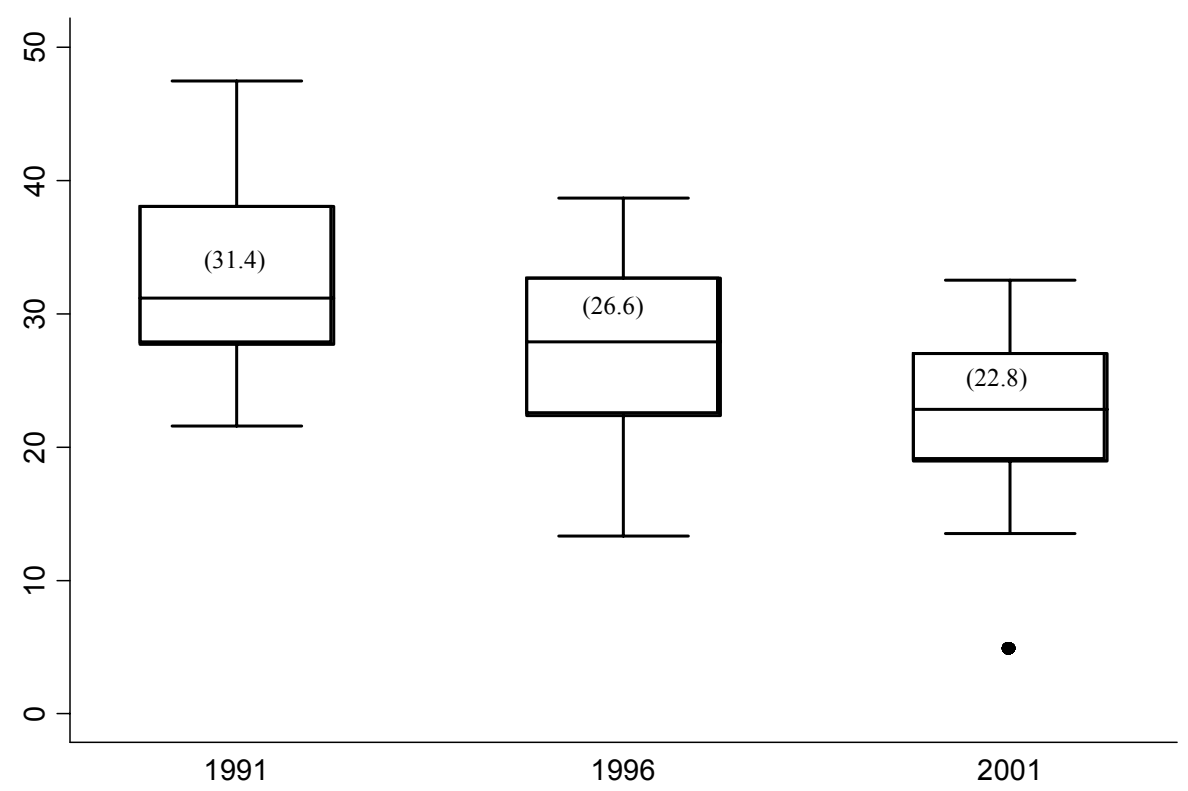

Panel B. Effective average tax rates on inward $\mathrm{FDI}^{2}$

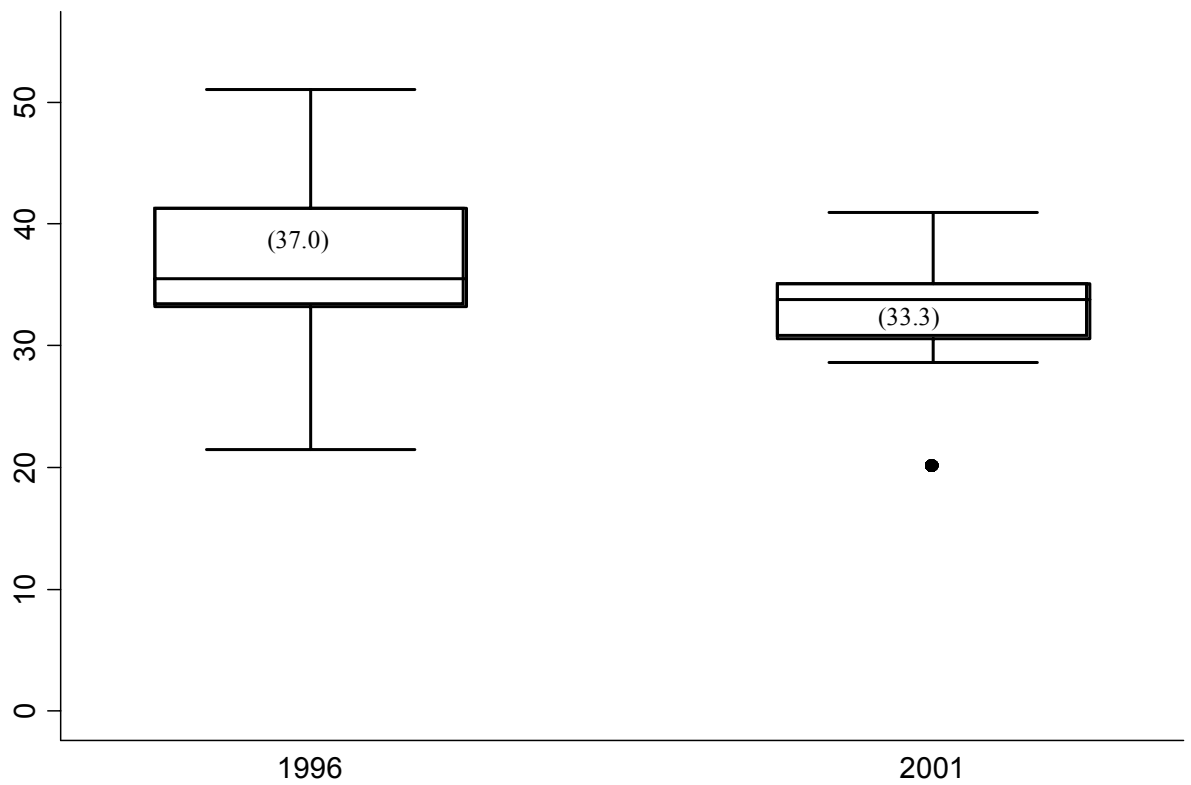

1. An effective tax rate on inward FDI refers to the rate applied to investors in the average investor country on income earned in a host country. An effective marginal rate applies to a marginal investment that earns the minimum rate of return after tax, while an effective average rate applies to an infra-marginal investment that earns some economic rent i.e. a project that earns more than the minimum required after-tax rate of return.

2. The box plot shows, in each year, the median OECD value of the effective tax rate imposed on inward FDI (the horizontal line in the box), the third and second quartiles of the cross-country distribution (the edges of each box) and the extreme values (the two whiskers extending from the box). Averages are provided in parentheses. Dots identify outlier observations. 2001 figures are based on 4.5 per cent inflation to ensure the consistency.

Source: OECD 
Figure 2. Variation of the effective tax rates on inward FDI applied by host country, 2001 ${ }^{1}$

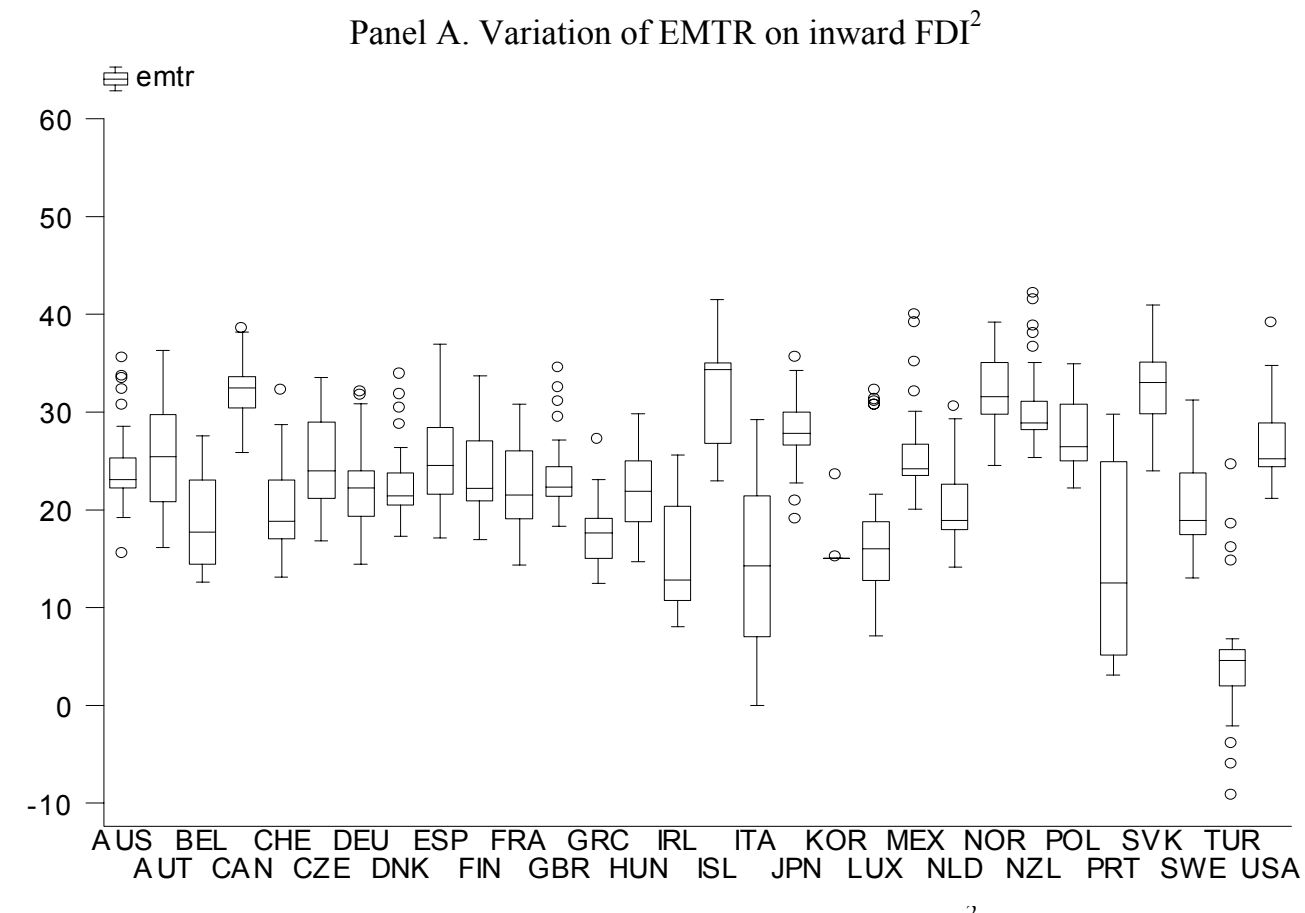

Panel B. Variation of EATR on inward $\mathrm{FDI}^{2}$

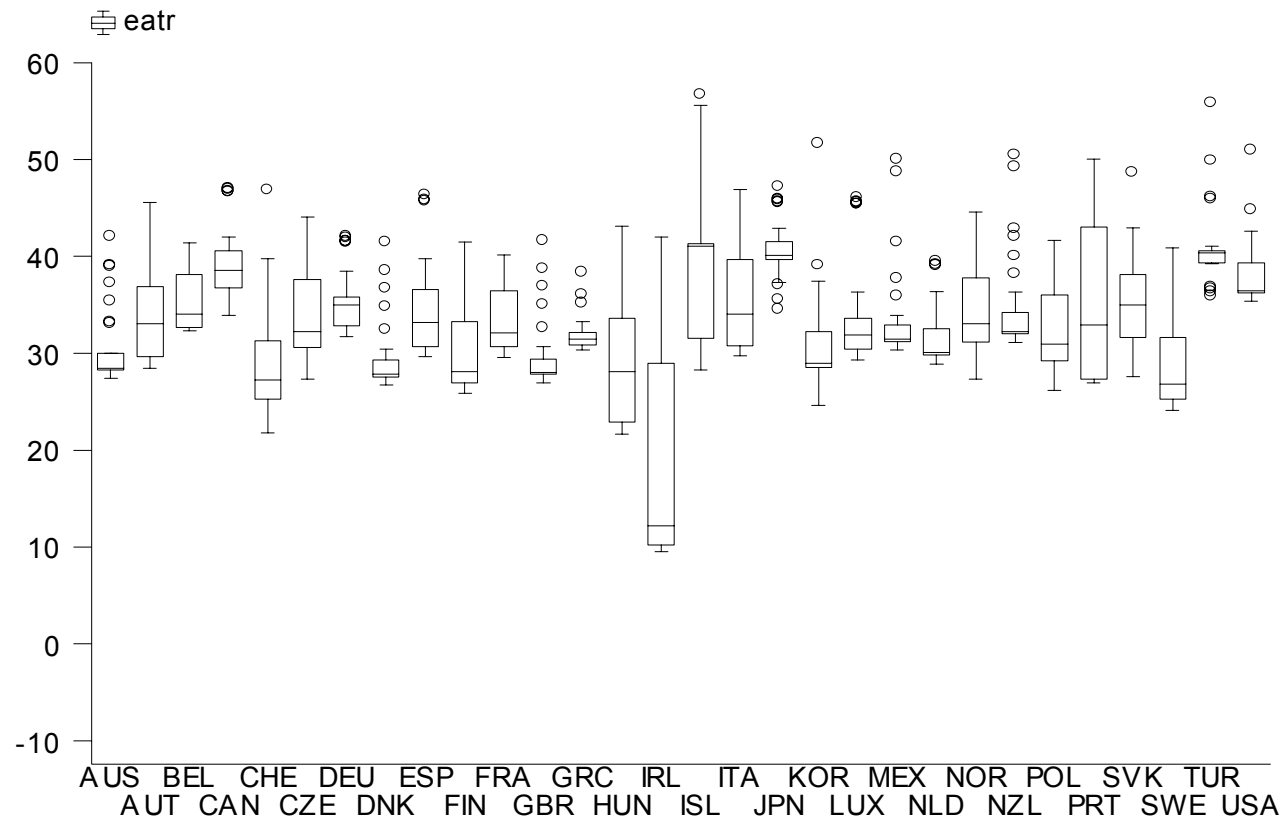

1. An effective tax rate on inward FDI refers to the rate applied to investors in the average investor country on income earned in a host country. An effective marginal rate applies to a marginal investment that earns the minimum rate of return after tax, while an effective average rate applies to an infra-marginal investment that earns some economic rent i.e. a project that earns more than the minimum required after-tax rate of return.

2. The box plot shows, for each host country, the variation of EMTR or EATR imposed on the investment from other countries. The median value of the effective tax rate is depicted by the horizontal line in the box, the third and second quartiles of the cross-country distribution by the edges of each box and the extreme values by the two whiskers extending from the box. Dots identify outlier observations.

Source: OECD 


\section{Other variables $^{14}$}

FDI

23. The FDI data used in regressions are drawn from OECD's International Direct Investment Statistics Yearbook and covers 28 OECD countries over the 1991-2000 period. ${ }^{15}$ Regressions are semi-logarithmic and focus on bilateral stocks of FDI between country pairs. Regressions for FDI flows were also run for robustness purposes and yielded similar results.

\section{Policy and non-policy influences}

24. Regressions are based on a specification derived from Markusen's (2002) reformulation of the OLI model of the MNE. In this model decisions to export or invest abroad are taken jointly. Moreover, foreign investment decisions can be of the horizontal or vertical type, depending on whether the MNE wishes to access local markets or fragment production into different stages. Horizontal investment is usually undertaken to exploit firm-specific knowledge capital of the parent firm and plant-specific economies of scale at the local level, while vertical investment is usually motivated by the wish to exploit the comparative advantages of the host country. To subsume both the trade versus investment choice and the horizontal versus vertical investment motives, an array of non-policy factors is included in the estimated model specification, reflecting the effects of $i$ ) gravity and economies of scale (combined market size, distance and transport costs), ii) factor proportions (dissimilarity in capital-labour ratios and human capital endowments), iii) plant-specific economies of scale (market size similarity). In constructing these variables, market size was proxied by GDP, human capital was proxied by the average educational attainment of the population and transport costs were proxied by a moving average of the ratio of CIF to FOB trade flows. ${ }^{16}$

25. Particular care was taken in specifying policy variables other than bilateral taxation that may have a bearing on FDI by affecting the host-country business environment and rates of return on investment in foreign affiliates. These cover three broad areas: border barriers, domestic product market regulation and labour market arrangements. Border barriers were proxied by the indicator of FDI restrictions of Golub (2003) and a dummy for participation (a home and host country) into a free trade area. Domestic product market regulation was proxied by combining the OECD indicators of regulation in seven non-manufacturing sectors (Conway and Nicoletti, 2006) and the OECD indicator of economy-wide product market regulation (Conway et al., 2005). Both indicators mostly measure the extent of barriers to entry and regulatory hurdles faced by domestic firms. However, the first focuses on a relatively narrow set of areas and sectors for a long time period (1975-2003), while the second covers a wider set of areas in the whole economy for only two periods (1998 and 2003). Combining the two exploits all the available information, but the implicit assumption is that cross-country differences in 1998 economy-wide regulations are representative of differences over the whole sample period. Labour market arrangements

14. Nicoletti et al., (2003) contains the source and the detailed description of each of the variables summarily discussed in this section.

15. The panel is balanced. To this end, some missing data was filled by using available antipodal bilateral data.

16. Other non-policy variables were included in regressions but were dropped in the final specification due to lack of significance, among these R\&D intensity, infrastructure endowments, bilateral exchange rates and exchange rate variability. 
were proxied by two indicators: tax wedges on labour income (from OECD's Taxing Wages) and the OECD indicator of employment protection legislation (OECD, 2004). ${ }^{17}$

26. Most of these policy variables can be thought to affect the MNE choice between trade and FDI as well as the type and location of FDI. For example, FDI restrictions can twist decisions towards exporting goods or services, while participation in free trade areas can encourage horizontal FDI that takes advantage of ease of access to and economies of scale of a larger market. Domestic restrictions to competition, regulatory hurdles or high labour costs (as implied by tax wedges or strict employment protection) can deter FDI in a particular location. ${ }^{18}$ Given that the MNE decision to invest abroad is often driven by a relative location advantage of the host country vis à vis the home country (e.g., in comparing the costs of producing at home and export to local markets versus the costs of producing in the local market, or in comparing costs in the home and host country for the purpose of fragmenting production), the variables proxying for domestic product and labour market arrangements in host countries were expressed as a ratio to the corresponding variables in the home country.

\section{Empirical model}

27. Denoting by $y$ the $\log$ of the FDI stock, by $X$ a vector of non-policy controls, by $P$ a vector of (non tax) policy indicators, by $T$ the indicator for the relevant tax rate, by $\alpha$ an unobserved component and by $u$ the error term, the general empirical specification of the bilateral FDI model is as follows:

$$
y_{i j t}=\sum_{x} \beta_{x} X_{i j t}+\sum_{P} \beta_{P} P_{i j t}+\beta T_{i j t}+\alpha_{i}+\alpha_{j}+\alpha_{t}+\alpha_{i t}+\alpha_{i j}+\alpha_{j t}+u_{i j t}
$$

where $i$ indexes the home country, $j$ indexes the host country and $t$ is the time period. It should be noted that some variables will be specific either to the home or to the host country (e.g., FDI restrictions) and will lack the bilateral dimension.

28. Panel data methods allow controlling for unobserved heterogeneity that is specific to each home and host country, home-host country pair, as well as, for time varying factors that are common to all countries and specific to home and host countries. The presence of these unobserved influences is particularly likely in bilateral FDI models because country interactions can be affected by institutions, culture, language, cyclical synchronicity, financial market linkages, etc. However, estimating a model capturing all these unobserved effects with a standard fixed effects approach may be problematic due to the extensive number of parameters to be estimated and the associated loss of degrees of freedom. To address this problem, two complementary estimation approaches are used. First, a simplified fixed effect model is estimated, in which the bilateral unobserved components are dropped:

$$
y_{i j t}=\sum_{x} \beta_{x} X_{i j t}+\sum_{z} \beta_{z} P_{i j t}+\beta T_{i j t}+\alpha_{i}+\alpha_{j}+\alpha_{t}+u_{i j t}
$$

FE

29. Recognising that estimates of this simplified model may suffer from omitted-variable bias, the analysis adopts the "transformed least square" (TLS) methodology introduced by Erkel-Rousse and Mirza (2002) in the context of empirical trade modelling. This approach expresses all variables in terms of

17. Other policy variables originally included in regressions but subsequently dropped for lack of significance or multicollinearity includes the Ginarte and Park (1997) indicator of intellectual property rights and an indicator of tariff and non-tariff barriers.

18. Alternatively, MNE may be attracted by a weakly competitive environment to exploit market power. 
deviations from an average home or host country. Thus, for any given variable $Z_{i j t}$ at time $t$ the operators $\Delta_{i}$ and $\Delta_{j}$ are defined such that:

$$
\begin{aligned}
& \Delta_{i}=Z_{i j t}-\frac{1}{I} \sum_{i} Z_{i j t} \\
& \Delta_{j}=Z_{i j t}-\frac{1}{J} \sum_{j} Z_{i j t}
\end{aligned}
$$

30. Using this approach the two following (home-country and host-country, respectively) equations can be derived from the general model above:

$$
\begin{array}{ll}
\Delta_{i} y_{i j t}=\sum_{x} \beta_{x} \Delta_{i} X_{i j t}+\sum_{P} \beta_{P} \Delta_{i} P_{i j t}+\beta \Delta_{i} T_{i j t}+\Delta_{i} \alpha_{i}+\Delta_{i} \alpha_{i t}+v_{i j t} & \text { TLS home country } \\
\Delta_{j} y_{i j t}=\sum_{x} \beta_{x} \Delta_{j} X_{i j t}+\sum_{p} \beta_{p} \Delta_{j} P_{i j t}+\beta \Delta_{i} T_{i j t}+\Delta_{j} \alpha_{j}+\Delta_{i} \alpha_{j t}+v_{i j t}^{\prime} & \text { TLS host country }
\end{array}
$$

where $\Delta_{i} \alpha_{i}$ and $\Delta_{j} \alpha_{j}$ represent deviations from the mean (home and host country) fixed effects, $\Delta_{i} \alpha_{i t}$ and $\Delta_{i} \alpha_{j t}$ indicate home and host country specific deviations that vary over time (proxied in empirical analysis by trends that are specific to the home or host country). Note that the residuals are now re-defined to include both the random errors and the deviations of bilateral fixed effects from their means, which are assumed to be i.i.d. random errors. ${ }^{19}$

31. In the TLS country specification bilateral FDI stocks and all the explanatory variables are expressed as deviations from the mean of home countries whereas in the TLS host country specification FDI stocks and the explanatory variables are expressed as deviations from the mean of host countries. The advantage of the TLS specifications and related assumptions is that in the home (host) country equation all unobserved host (home) country-specific effects as well as common time trends are captured in a nonparametric way before estimating the equation. Thus, only home (host)-specific country effects and home (host)-specific trends need to be estimated. This greatly reduces the number of parameters to be estimated, while leaving the properties of the relevant coefficient estimates unchanged. Thus, the advantage of the TLS home country and TLS host country equations is that the estimated parameters $\left(\beta_{x}, \beta_{p}, \beta\right)$ are the same as in the general specification and (under the null of i.i.d. random errors) their estimates should also be similar in the two regressions.

\section{Regression results}

32. In this section regression results are reported for several model specifications that vary mostly according to the number of policy variables used to describe the business environment in the home and

19. In other terms:

$$
\begin{aligned}
& v_{i j t}=\Delta_{i} u_{i j t}+\Delta_{i} \alpha_{i j} \\
& v_{i j t}^{\prime}=\Delta_{j} u_{i j t}+\Delta_{j} \alpha_{i j}
\end{aligned}
$$

This is the same assumption made by Erkel-Rousse and Mirza (2002). 
host countries. Tax elasticise are estimated, using both the AETR and METR indicators as well as the host country corporate tax rate. To avoid confusion, it should be noted that estimates for the first two indicators are not strictly comparable because the number of observations differs substantially across regressions due to the shorter sample period available for the AETR. Following the discussion in de Mooij and Ederveen (2005) and Bénassy-Quéré et al., (2003), some regressions include a dummy variable describing alternative tax schemes in the home country to test whether tax elasticity estimates are influenced by these tax regimes. This variable takes a value of one if an exemption scheme is in operation in a home country and zero if a credit scheme is in operation. ${ }^{20}$ Finally, some regressions also include a variable summarising bilateral taxation regimes of the home country with other host countries that are sufficiently "similar" to induce potential crowding out (or crowding in) of FDI from the host country to those other countries (or vice versa). This "diversion" effect is usually ignored in empirical studies of tax and FDI and this omission could be a possible source of bias in tax elasticity estimates. ${ }^{21}$ In all regression specifications, results are shown for the TLS home country, TLS host country and FE estimation approaches to check the robustness of the estimates to different estimation methods. The time period for the panel regressions is restricted to either 1991-1999 (METR) or 1996-1999 (AETR) because some of the explanatory variables were not available for the whole period 1991-2000.

33. Before discussing tax elasticity estimates in the various model specifications, it is useful to comment on regression results for the basic non-policy variables, which are remarkably stable across equations. As already found in Nicoletti et al., (2003), coefficient estimates for variables reflecting market size, transport costs, economies of scale (size similarity) and factor proportions are generally significant and signed according to priors. Taken together, the findings of a positive effect of market size similarity and a negative effect of factor dissimilarity support the conjecture that FDI is driven mainly by horizontal (market access) motives among the OECD countries covered by the sample. It is also worth noting that, in all specifications, the null of no country or time effects is strongly rejected by the data, pointing to a significant influence of unobserved factors on the intensity of bilateral FDI among country pairs.

34. Tables 3 and 4 focus on tax elasticity estimates in the simple model in which no other policies shaping the business environment are included. The results for the AETR and METR computed by Yoo (2003) suggest that effective corporate tax rates have a significant negative effect on FDI decisions by MNE. Depending on the estimation approach, the estimated semi-elasticities suggest that, on average, a one percentage point increase in the METR leads to a 2 to $4.5 \%$ fall in the stock of FDI invested in a host country. As expected, the semi-elasticities computed for AETR are larger, with one percentage point increase leading to a 3.5 to $5.5 \%$ fall in FDI. ${ }^{22}$ The corresponding elasticities are 0.6-1.2 for the METR and 0.9-1.5 for the AETR. Comparison with the results reported in Tables 1 and 2 suggests that these estimated elasticities are in line with recent studies using a range of indicators of the tax burden on FDI.

20. Under the exemption scheme repatriated profits from foreign affiliates are exempt from corporate taxation in a home country and are taxed only according to the host-country tax rate whereas under the credit scheme MNE are allowed to deduct taxes paid abroad by their foreign affiliates from their tax payments in the home country. Hence, ceteris paribus under credit and exemption systems, host country taxes exert different incentives for parent companies to undertake FDI.

21. The variable capturing possible FDI diversion is constructed as follows. A similarity index is computed taking into account all non-policy characteristics of host and home country-pairs (over sample period averages). For each country pair, similar country pairs are defined as those whose similarity index deviates by no more than one standard error. For each country pair, the diversion variable is then computed as the (simple) average bilateral METR or AETR over this subset of similar country pairs.

22. Similar results are obtained when outward FDI flows are used as endogenous variables instead of FDI stocks. 
Table 3. The effect of the AETR on FDI stocks - years 1996-1999a)

\begin{tabular}{|c|c|c|c|c|c|c|c|}
\hline & \multicolumn{7}{|c|}{ Outward FDI outstock -taxation } \\
\hline & \multicolumn{2}{|c|}{ TLS } & \multirow{2}{*}{ FE } & \multicolumn{2}{|c|}{ TLS } & \multirow{2}{*}{\multicolumn{2}{|c|}{ FE }} \\
\hline & Home & Host & & Home & Home & & \\
\hline & $A$ & $B$ & $C$ & $D$ & $E$ & $F$ & $G$ \\
\hline Total GDP & $\begin{array}{c}4.508 \\
{[4.22]^{\star \star \star}}\end{array}$ & $\begin{array}{c}1.776 \\
{[1.72]^{*}}\end{array}$ & $\begin{array}{l}0.697 \\
{[0.85]}\end{array}$ & $\begin{array}{c}4.532 \\
{[4.26]^{\star \star \star}}\end{array}$ & $\begin{array}{c}4.552 \\
{[4.29]^{\star * \star}}\end{array}$ & $\begin{array}{l}0.690 \\
{[0.85]}\end{array}$ & $\begin{array}{l}0.679 \\
{[0.83]}\end{array}$ \\
\hline Size similarity & $\begin{array}{c}2.505 \\
{[4.76]^{\star \star \star}}\end{array}$ & $\begin{array}{c}1.053 \\
{[2.09]^{\star *}}\end{array}$ & $\begin{array}{l}0.549 \\
{[1.33]}\end{array}$ & $\begin{array}{c}2.521 \\
{[4.80]^{\star \star \star}}\end{array}$ & $\begin{array}{c}2.530 \\
{[4.83]^{\star \star \star}}\end{array}$ & $\begin{array}{l}0.551 \\
{[1.34]}\end{array}$ & $\begin{array}{c}0.544 \\
{[1.32]}\end{array}$ \\
\hline Factor dissimilarity & $\begin{array}{c}-0.245 \\
{[2.95]^{\star * \star}}\end{array}$ & $\begin{array}{c}-0.335 \\
{[4.20]^{\star \star \star}}\end{array}$ & $\begin{array}{c}-0.314 \\
{[3.69]^{\star * \star}}\end{array}$ & $\begin{array}{c}-0.253 \\
{[3.05]^{\star \star \star}}\end{array}$ & $\begin{array}{c}-0.250 \\
{[3.01]^{\star \star \star}}\end{array}$ & $\begin{array}{c}-0.322 \\
{[3.78]^{\star * \star}}\end{array}$ & $\begin{array}{c}-0.318 \\
{[3.73]^{\star \star \star}}\end{array}$ \\
\hline Human capital dissimilarity & $\begin{array}{c}-3.213 \\
{[6.72]^{\star * *}}\end{array}$ & $\begin{array}{c}-3.685 \\
{[7.83]^{\star \star \star}}\end{array}$ & $\begin{array}{c}-3.256 \\
{[7.08]^{* * \star}}\end{array}$ & $\begin{array}{c}-3.130 \\
{[6.54]^{\star \star \star}}\end{array}$ & $\begin{array}{c}-3.120 \\
{[6.54]^{* * *}}\end{array}$ & $\begin{array}{c}-3.149 \\
{[6.89]^{* * *}}\end{array}$ & $\begin{array}{c}-3.151 \\
{[6.89]^{* * *}}\end{array}$ \\
\hline Transport costs & $\begin{array}{c}-0.422 \\
{[2.27]^{* *}}\end{array}$ & $\begin{array}{l}-0.170 \\
{[0.77]}\end{array}$ & $\begin{array}{l}-0.363 \\
{[1.63]^{*}}\end{array}$ & $\begin{array}{c}-0.418 \\
{[2.26]^{\star *}}\end{array}$ & $\begin{array}{c}-0.416 \\
{[2.26]^{\star *}}\end{array}$ & $\begin{array}{l}-0.359 \\
{[1.62]^{*}}\end{array}$ & $\begin{array}{l}-0.357 \\
{[1.62]^{\star}}\end{array}$ \\
\hline AETR $^{b}$ & $\begin{array}{c}-0.057 \\
{[5.38]^{\star \star \star}}\end{array}$ & $\begin{array}{c}-0.036 \\
{[3.52]^{\star \star \star}}\end{array}$ & $\begin{array}{c}-0.042 \\
{[4.81]^{\star \star *}}\end{array}$ & $\begin{array}{c}-0.053 \\
{[4.76]^{* * *}}\end{array}$ & & $\begin{array}{c}-0.038 \\
{[4.18]^{\star * *}}\end{array}$ & \\
\hline TAX exempt & & & & $\begin{array}{l}0.418 \\
{[1.35]}\end{array}$ & & $\begin{array}{c}0.465 \\
{[1.81]^{*}}\end{array}$ & \\
\hline TAX exempt*AETR & & & & & $\begin{array}{c}-0.051 \\
{[4.52]^{\star * *}}\end{array}$ & & $\begin{array}{c}-0.036 \\
{[3.90]^{* * *}}\end{array}$ \\
\hline TAX credit*AETR & & & & & $\begin{array}{c}-0.061 \\
{[5.55]^{\star \star \star}}\end{array}$ & & $\begin{array}{c}-0.046 \\
{[5.14]^{\star * *}}\end{array}$ \\
\hline Constant & $\begin{array}{l}0.082 \\
{[0.02]}\end{array}$ & $\begin{array}{l}-0.901 \\
{[0.40]}\end{array}$ & $\begin{array}{l}3.797 \\
{[0.16]}\end{array}$ & $\begin{array}{l}-0.168 \\
{[0.04]}\end{array}$ & $\begin{array}{l}-0.300 \\
{[0.07]}\end{array}$ & $\begin{array}{l}3.333 \\
{[0.14]}\end{array}$ & $\begin{array}{l}3.907 \\
{[0.17]}\end{array}$ \\
\hline Observations & 1609 & 1624 & 1607 & 1609 & 1609 & 1607 & 1607 \\
\hline R-squared & 0.774 & 0.624 & 0.8471 & 0.774 & 0.774 & 0.848 & 0.848 \\
\hline
\end{tabular}

0.774

absolute value of t-statistics in brackets.

${ }^{*}$ significant at $5 \%$ level; ** significant at $1 \%$ level.

28 home and host countries included

b) Average effective tax rate on FDI. 
Table 4. The effect of the METRs on FDI stocks - years 1991-1999

\begin{tabular}{|c|c|c|c|c|c|c|c|c|c|c|c|c|}
\hline & \multicolumn{12}{|c|}{ Outward FDI outstock -taxation } \\
\hline & \multicolumn{2}{|c|}{ TLS } & \multirow{2}{*}{ FE } & \multicolumn{4}{|c|}{ TLS } & \multirow{2}{*}{\multicolumn{3}{|c|}{$\mathrm{FE}$}} & TLS & \multirow{2}{*}{$\mathrm{FE}$} \\
\hline & Home & Host & & Home & Home & Home & Host & & & & Home & \\
\hline & $A$ & $B$ & $C$ & $D$ & $E$ & $F$ & $G$ & $H$ & 1 & $J$ & $K$ & $L$ \\
\hline Total GDP & $\begin{array}{c}4.344 \\
{[7.18]^{\star \star \star}}\end{array}$ & $\begin{array}{c}1.891 \\
{[3.36]^{\star \star \star}}\end{array}$ & $\begin{array}{c}0.885 \\
{[2.66]^{\star \star \star}}\end{array}$ & $\begin{array}{c}4.413 \\
{[7.30]^{* * *}}\end{array}$ & $\begin{array}{c}4.366 \\
7.22]^{\star \star \star}\end{array}$ & $\begin{array}{c}3.829 \\
{[6.29]^{\star * \star}}\end{array}$ & $\begin{array}{c}2.317 \\
{[4.20\}^{\star * *}}\end{array}$ & $\begin{array}{c}0.893 \\
{[2.68]^{* \star *}}\end{array}$ & $\begin{array}{c}0.885 \\
{[2.66]^{* * *}}\end{array}$ & $\begin{array}{c}0.861 \\
{[2.65]^{\star \star \star}}\end{array}$ & $\begin{array}{c}3.832 \\
{[6.29]^{\star \star \star}}\end{array}$ & $\begin{array}{c}0.861 \\
{[2.65]^{\star \star *}}\end{array}$ \\
\hline Size similarity & $\begin{array}{c}2.542 \\
{[8.62]^{\star \star \star}}\end{array}$ & $\begin{array}{c}1.194 \\
{[4.36]^{* * *}}\end{array}$ & $\begin{array}{c}0.681 \\
{[4.02]^{\star \star \star}}\end{array}$ & $\begin{array}{c}2.580 \\
{[8.76]^{\star \star \star *}}\end{array}$ & $\begin{array}{c}2.554 \\
{[8.67]^{\star \star \star}}\end{array}$ & $\begin{array}{c}2.238 \\
{[7.54]^{\star \star *}}\end{array}$ & $\begin{array}{c}1.357 \\
{[5.01]^{\star \star \star}}\end{array}$ & $\begin{array}{c}0.689 \\
{[4.06]^{\star \star \star}}\end{array}$ & $\begin{array}{c}0.682 \\
{[4.02]^{\star \star \star}}\end{array}$ & $\begin{array}{c}0.616 \\
{[3.72]^{\star \star *}}\end{array}$ & $\begin{array}{c}2.240 \\
\{7.54]^{\star \star \star}\end{array}$ & $\begin{array}{c}0.616 \\
{[3.72]^{* * *}}\end{array}$ \\
\hline Factor dissimilarity & $\begin{array}{c}-0.266 \\
{[4.02]^{\star \star \star}}\end{array}$ & $\begin{array}{c}-0.358 \\
{[5.35]^{\star \star \star}}\end{array}$ & $\begin{array}{l}-0.258 \\
{[3.70]}\end{array}$ & $\begin{array}{c}-0.275 \\
{[4.16]^{* * *}}\end{array}$ & $\begin{array}{c}-0.267 \\
{[4.05]^{\star \star \star}}\end{array}$ & $\begin{array}{c}-0.309 \\
{[4.67]^{* * *}}\end{array}$ & $\begin{array}{c}-0.389 \\
{[5.95]^{\star * \star}}\end{array}$ & $\begin{array}{c}-0.265 \\
{[3.79]^{\star * *}}\end{array}$ & $\begin{array}{c}-0.259 \\
{[3.70]^{* * *}}\end{array}$ & $\begin{array}{c}-0.328 \\
{[4.64]^{\star \star \star}}\end{array}$ & $\begin{array}{c}-0.311 \\
{[4.70]^{\star \star \star}}\end{array}$ & $\begin{array}{c}-0.328 \\
{[4.64]^{\star \star \star}}\end{array}$ \\
\hline Human capital dissimilarity & $\begin{array}{c}-2.463 \\
{[8.69]^{* \star *}}\end{array}$ & $\begin{array}{c}-2.691 \\
{[9.66]^{* \star *}}\end{array}$ & $\begin{array}{c}-2.723 \\
{[9.38]^{\star * *}}\end{array}$ & $\begin{array}{c}-2.372 \\
{[8.39]^{* * *}}\end{array}$ & $\begin{array}{c}-2.425 \\
{[8.59]^{* * *}}\end{array}$ & $\begin{array}{c}-2.318 \\
{[8.27]^{* * *}}\end{array}$ & $\begin{array}{l}-2.600 \\
{[9.13]}\end{array}$ & $\begin{array}{c}-2.617 \\
{[9.04]^{\star * *}}\end{array}$ & $\begin{array}{c}-2.704 \\
{[9.36]^{* * *}}\end{array}$ & $\begin{array}{c}-2.411 \\
{[8.66]^{* * *}}\end{array}$ & $\begin{array}{c}-2.282 \\
{[8.19]^{\star \star \star}}\end{array}$ & $\begin{array}{c}-2.407 \\
{[8.68]^{* * *}}\end{array}$ \\
\hline Transport costs & $\begin{array}{c}-0.603 \\
{[4.24]^{\star \star \star}}\end{array}$ & $\begin{array}{c}-0.585 \\
{[3.85]^{\star * \star}}\end{array}$ & $\begin{array}{c}-0.801 \\
{[5.88]^{\star * *}}\end{array}$ & $\begin{array}{c}-0.596 \\
{[4.20]^{* * *}}\end{array}$ & $\begin{array}{c}-0.595 \\
{[4.21]^{\star \star \star}}\end{array}$ & $\begin{array}{c}-0.808 \\
{[6.04]^{\star * *}}\end{array}$ & $\begin{array}{c}-0.823 \\
{[6.13]^{\star \star \star}}\end{array}$ & $\begin{array}{c}-0.794 \\
{[5.85]^{\star \star \star}}\end{array}$ & $\begin{array}{c}-0.798 \\
{[5.86]^{* * *}}\end{array}$ & $\begin{array}{c}-0.959 \\
{[7.84]^{\star \star *}}\end{array}$ & $\begin{array}{c}-0.797 \\
{[5.96]^{\star \star \star}}\end{array}$ & $\begin{array}{c}-0.958 \\
{[7.82]^{* * *}}\end{array}$ \\
\hline $\begin{array}{l}\text { METR }^{\mathrm{b}} \\
\text { TAX exempt }\end{array}$ & $\begin{array}{c}-0.046 \\
{[7.01]^{* \star *}}\end{array}$ & $\begin{array}{c}-0.027 \\
{[5.36]^{* * *}}\end{array}$ & $\begin{array}{c}-0.022 \\
{[5.37]^{* * *}}\end{array}$ & $\begin{array}{c}-0.044 \\
{[6.54]^{* * *}} \\
0.412 \\
{[2.25]^{* *}}\end{array}$ & & $\begin{array}{c}-0.038 \\
{[5.79]^{* * *}}\end{array}$ & $\begin{array}{c}-0.022 \\
{[4.39]^{* * *}}\end{array}$ & $\begin{array}{c}-0.020 \\
{[4.91]^{\star * *}} \\
0.411 \\
{[2.61]^{\star \star *}}\end{array}$ & & $\begin{array}{c}-0.017 \\
{[4.21]^{* * *}}\end{array}$ & & \\
\hline TAX exempt*METR & & & & & $\begin{array}{c}-0.043 \\
{[6.06]^{\star \star \star}}\end{array}$ & & & & $\begin{array}{c}-0.021 \\
{[4.63]^{\star \star \star}}\end{array}$ & & $\begin{array}{c}-0.035 \\
{[4.93]^{\star \star \star}}\end{array}$ & $\begin{array}{c}-0.016 \\
{[3.73]^{\star * *}}\end{array}$ \\
\hline TAX credit*METR & & & & & $\begin{array}{c}-0.048 \\
{[7.15]^{\star \star \star}}\end{array}$ & & & & $\begin{array}{c}-0.023 \\
{[5.17]^{\star \star \star}}\end{array}$ & & $\begin{array}{c}-0.041 \\
{[5.89]^{\star \star \star}}\end{array}$ & $\begin{array}{c}-0.017 \\
{[3.83]^{\star \star \star}}\end{array}$ \\
\hline EMTR elsewhere & & & & & & $\begin{array}{c}0.015 \\
{[2.20]^{* *}}\end{array}$ & $\begin{array}{c}0.014 \\
{[2.31]^{\star *}}\end{array}$ & & & $\begin{array}{c}0.009 \\
{[1.49]}\end{array}$ & $\begin{array}{c}0.016 \\
{[2.38]^{* *}}\end{array}$ & $\begin{array}{l}0.009 \\
{[1.51]}\end{array}$ \\
\hline Constant & $\begin{array}{l}-1.032 \\
{[1.10]}\end{array}$ & $\begin{array}{l}0.885 \\
{[1.41]}\end{array}$ & $\begin{array}{l}-2.712 \\
{[0.30]}\end{array}$ & $\begin{array}{l}-1.279 \\
{[1.35]}\end{array}$ & $\begin{array}{l}-1.159 \\
{[1.23]}\end{array}$ & $\begin{array}{l}0.021 \\
{[1.35]}\end{array}$ & $\begin{array}{l}0.803 \\
{[1.30]}\end{array}$ & $\begin{array}{l}-3.378 \\
{[0.38]}\end{array}$ & $\begin{array}{l}-2.739 \\
{[0.43]}\end{array}$ & $\begin{array}{l}-1.819 \\
{[0.21]}\end{array}$ & $\begin{array}{l}-0.111 \\
{[0.12]}\end{array}$ & $\begin{array}{l}-1.827 \\
{[0.21]}\end{array}$ \\
\hline Observations & 3099 & 3103 & 3083 & 3099 & 3099 & 2960 & 2960 & 3083 & 3083 & 2935 & 2960 & 2935 \\
\hline R-squared & 0.743 & 0.639 & 0.840 & 0.743 & 0.743 & 0.759 & 0.617 & 0.840 & 0.840 & 0.851 & 0.759 & 0.851 \\
\hline
\end{tabular}

a) Absolute value of t-statistics in brackets.

significant at $5 \%$ level; ** significant at $1 \%$ level.

28 home and host countries included

b) Marginal effective tax rate on FDI 
35. Tables 3 and 4 also explore the impact of credit or exemption systems and the possibility of FDI diversion due to changes in tax regimes in similar host countries (from the point of view of the home country). Consistent with priors, results suggest that ceteris paribus moving to an exemption system tends to increase the stock of bilateral FDI. However, in line with previous findings by Slemrod (1990) and Bénassy-Quére et al., (2003), there is no evidence that the response of FDI to changes in either METR or AETR differs across countries that enjoy credit or exemption systems. As suggested by Tanzi and Bovenberg (1990) and Altshuler and Newlon (2003), excess foreign credit positions and tax planning strategies of MNE may make the distinction between credit and exemption countries unimportant in practice. As to diversion effects, a significant positive coefficient is found for the variable that proxies for taxation in alternative but similar host countries, suggesting that increases in the METR in these countries will tend to divert FDI towards the host country (and vice versa) ${ }^{23}$ Interestingly, taking diversion into account reduces the value of the estimated tax elasticities. Hence, omission of this variable in previous studies may have led to overestimates of tax elasticities.

36. One criticism of studies using AETR and METR is that they may lead to biased elasticity estimates because these indicators are unable to account for MNE strategies aimed at minimising tax burdens (Swenson, 1994). For instance, MNE can rely on thin capitalisation of high-taxed subsidiaries, defer tax payment in various ways and rely on triangular structures that provide multiple tax advantages. ${ }^{24}$ These features are very difficult to model within standard AETR or METR frameworks. If tax planning strategies are effective, bilateral measures of the tax burden on FDI could be outpaced in regressions by the host country statutory corporate tax rate, ${ }^{25}$ which becomes a more relevant tax variable for MNE under these conditions. This conjecture is tested in Table 5, by replacing the METR and AETR with the corporate tax rate in host countries. The estimated effect of the statutory tax rate is statistically insignificant, suggesting either that this procedure is not capturing the potential impact of tax planning or that tax planning is not so extensive as to eliminate the impact of home country taxation of foreign-source income.

23. Unfortunately, the sample period is too short to estimate the corresponding effect on AETR regressions.

24. See OECD (2006) for a long list of such strategies in both exemption and credit systems.

25. Alternatively, if deferral was the main form of tax planning, the relevant tax variables could be AETR and METR of the host country alone (excluding taxation in the home country). 
Table 5. The effect of corporate tax rates on FDI stocks - years 1991-1999a

\begin{tabular}{|c|c|c|c|c|c|}
\hline & \multicolumn{5}{|c|}{ Outward FDI outstock -taxation } \\
\hline & TLS & \multirow{2}{*}{ FE } & \multirow{2}{*}{\multicolumn{3}{|c|}{ FE }} \\
\hline & Host & & & & \\
\hline & $A$ & $B$ & $C$ & $D$ & $E$ \\
\hline Total GDP & $\begin{array}{c}1.716 \\
{[3.03]^{\star * *}}\end{array}$ & $\begin{array}{c}0.848 \\
{[2.53]^{\star * *}}\end{array}$ & $\begin{array}{c}0.861 \\
{[2.57]^{\star * *}}\end{array}$ & $\begin{array}{c}0.850 \\
{[2.54]^{\star * *}}\end{array}$ & $\begin{array}{c}0.859 \\
{[2.39]^{* *}}\end{array}$ \\
\hline Size similarity & $\begin{array}{c}1.111 \\
{[4.03]^{\star * *}}\end{array}$ & $\begin{array}{c}0.676 \\
{[3.96]^{\star \star *}}\end{array}$ & $\begin{array}{c}0.687 \\
{[4.02]^{\star * *}}\end{array}$ & $\begin{array}{c}0.685 \\
{[4.01]^{\star * *}}\end{array}$ & $\begin{array}{c}0.681 \\
{[3.73]^{\star * *}}\end{array}$ \\
\hline Factor dissimilarity & $\begin{array}{c}-0.369 \\
{[5.48]^{\star * *}}\end{array}$ & $\begin{array}{c}-0.275 \\
{[3.91]^{\star * *}}\end{array}$ & $\begin{array}{c}-0.282 \\
{[4.01]^{\star * *}}\end{array}$ & $\begin{array}{c}-0.271 \\
{[3.84]^{* * *}}\end{array}$ & $\begin{array}{c}-0.275 \\
{[3.89]^{\star * *}}\end{array}$ \\
\hline Human capital dissimilarity & $\begin{array}{c}-2.848 \\
{[10.26]^{\star * *}}\end{array}$ & $\begin{array}{c}-2.884 \\
{[9.96]^{\star * *}}\end{array}$ & $\begin{array}{c}-2.736 \\
{[9.49]^{\star \star *}}\end{array}$ & $\begin{array}{c}-2.781 \\
{[9.65]^{* * *}}\end{array}$ & $\begin{array}{c}-2.885 \\
{[9.96]^{* * *}}\end{array}$ \\
\hline Transport costs & $\begin{array}{c}-0.585 \\
{[3.84]^{* * *}}\end{array}$ & $\begin{array}{c}-0.791 \\
{[5.80]^{\star * *}}\end{array}$ & $\begin{array}{c}-0.782 \\
{[5.77]^{\star * *}}\end{array}$ & $\begin{array}{c}-0.792 \\
{[5.90]^{* * *}}\end{array}$ & $\begin{array}{c}-0.791 \\
{[5.80]^{\star * *}}\end{array}$ \\
\hline Corporate tax rate ${ }^{b}$ & $\begin{array}{l}-0.000 \\
{[0.02]}\end{array}$ & $\begin{array}{l}-0.004 \\
{[0.40]}\end{array}$ & $\begin{array}{l}-0.004 \\
{[0.40]}\end{array}$ & & $\begin{array}{l}-0.003 \\
{[0.38]}\end{array}$ \\
\hline TAX exempt & & & $\begin{array}{c}0.523 \\
{[3.38]^{\star * *}}\end{array}$ & & \\
\hline TAX exempt ${ }^{*}$ Corporate tax & & & & $\begin{array}{l}0.001 \\
{[0.07]}\end{array}$ & \\
\hline TAX credit ${ }^{\star}$ Corporate tax & & & & $\begin{array}{l}-0.010 \\
{[1.07]}\end{array}$ & \\
\hline Tax elsewhere & & & & & $\begin{array}{l}0.007 \\
{[0.10]}\end{array}$ \\
\hline Constant & $\begin{array}{l}0.682 \\
{[1.09]}\end{array}$ & $\begin{array}{l}-2.424 \\
{[0.27]}\end{array}$ & $\begin{array}{l}-3.296 \\
{[0.36]}\end{array}$ & $\begin{array}{l}-2.653 \\
{[0.29]}\end{array}$ & $\begin{array}{l}-3.014 \\
{[0.27]}\end{array}$ \\
\hline $\begin{array}{l}\text { Observations } \\
\text { R-squared }\end{array}$ & $\begin{array}{l}3103 \\
0.635\end{array}$ & $\begin{array}{l}3083 \\
0.838\end{array}$ & $\begin{array}{l}3083 \\
0.839\end{array}$ & $\begin{array}{l}3083 \\
0.839\end{array}$ & $\begin{array}{l}3083 \\
0.838\end{array}$ \\
\hline
\end{tabular}

a) Absolute value of t-statistics in brackets.

${ }^{*}$ significant at $5 \%$ level; ** significant at $1 \%$ level.

b) Statutory corporate tax rate 
37. As already mentioned, host country tax rates and bilateral tax arrangements are only two of the policy factors that may affect the attractiveness of a host country for international investors. The regressions in Table 6 extend the basic tax and FDI model to cover a number of other policies that are potentially important for MNE location choices, focusing on border barriers, product market regulation and labour market arrangements. Regression results show that the estimated effects of these policies correspond to priors. Increasing openness by participating in a free trade area tends to increase FDI stocks in the host country. The effect of easing FDI restrictions is less clear-cut and lacks robustness across estimation approaches and model specifications, perhaps reflecting insufficient in sample variability of this indicator, especially in AETR regressions. Both relatively high employment protection and tax wedges tend to curb FDI stocks and the same is true for anticompetitive regulations. Most of these effects are significant at very high levels and are robust across estimation methods and model specifications. The exception is employment protection, which loses significance in the AETR equations, probably reflecting the fact that very few changes in the indicator have occurred over the 1996-1999 period.

38. These extended regressions can address two questions: What is the effect of including broader measures of the business environment on estimated tax elasticities? What is the relative importance of tax and other policies in determining the FDI attractiveness of a country? The answers they provide are very instructive for tax and FDI analyses and may also have broader policy implications. The results show that including other policy variables more than halves tax elasticity estimates, suggesting that most empirical studies of the tax and FDI link suffer from a serious omitted-variable bias that grossly overstates the response of FDI to taxes. ${ }^{26}$ More importantly, regression results suggest that, while taxation preserves a small but significant negative effect on FDI, this effect is dwarfed by the effect of other policies. By way of comparison, the effect on FDI of a one standard deviation change in the tax wedge on labour income is around ten times larger than the effect of a similar change in the METR or AETR ${ }^{27}$, while the effect of a one standard deviation change in domestic product market regulation and EPL is around twice as large as the effect of similar change in the METR or AETR. Figure 3 shows the average contributions of policy factors to the deviations in FDI. ${ }^{28}$ This decomposition confirms that taxation contributes relatively little to explaining FDI compared with other policies. Taken together, policies seem to have a substantial effect on FDI, around $40 \%$ of the deviation in FDI is explained by policy factors and $60 \%$ by non-policy related factors as well as home and host country-specific effects and time-fixed effects. These results, if confirmed by further analysis, would tend to tone down the public debate around the relevance of cross-country differences in corporate tax policies for FDI. Incidentally, this would seem to be in line with business surveys that usually do not put host country taxation at the top of MNE concerns when choosing locations. Nonetheless, the fact that there is a tendency for both convergence and decline over time of corporate tax rates calls for further research in this area.

26. The results concerning credit and tax exemption schemes as well as the variable capturing possible FDI diversion are relatively robust to the inclusion of other policy variables, although the statistical significance of the FDI diversion variable is reduced.

27. The difference between the effects of the tax wedge on labour income and AETR is even larger in the host country regression due too the smaller estimated semi-elasticity of AETR.

28. Contributions are based on the results of host country equations (B) and (E) in Table 6, panel A and are computed taking average over the estimation period and investor country. 
Table 6. The effect of the METR and AETR on FDI stocks ${ }^{a}$

PANEL A

\begin{tabular}{|c|c|c|c|c|c|c|c|c|}
\hline & \multicolumn{8}{|c|}{ Outward FDI outstock -full model } \\
\hline & \multicolumn{2}{|c|}{ TLS } & \multirow{2}{*}{$\mathrm{FE}^{\mathrm{b}}$} & \multicolumn{2}{|c|}{ TLS } & \multirow{2}{*}{$F E^{b}$} & \multirow{2}{*}{$\frac{\text { TLS }}{\text { Host }^{b}}$} & \multirow{2}{*}{$\mathrm{FE}^{\mathrm{b}}$} \\
\hline & Home $^{\text {b }}$ & $\mathrm{Host}^{\mathrm{b}}$ & & Home $^{\text {b }}$ & $\mathrm{Host}^{b}$ & & & \\
\hline & $A$ & $B$ & $C$ & $D$ & $E$ & $F$ & $G$ & $H$ \\
\hline Total GDP & $\begin{array}{c}5.177 \\
{[7.86]^{* * *}}\end{array}$ & $\begin{array}{c}1.428 \\
{[2.40]^{\star *}}\end{array}$ & $\begin{array}{c}0.688 \\
{[2.20]^{* *}}\end{array}$ & $\begin{array}{c}8.113 \\
{[5.48]^{* * *}}\end{array}$ & $\begin{array}{l}0.094 \\
{[0.07]}\end{array}$ & $\begin{array}{l}1.542 \\
{[1.62]}\end{array}$ & $\begin{array}{c}1.332 \\
{[2.23]^{\star *}}\end{array}$ & $\begin{array}{c}0.644 \\
{[2.05]^{\star *}}\end{array}$ \\
\hline Size similarity & $\begin{array}{c}3.019 \\
{[9.50]^{\star \star \star}}\end{array}$ & $\begin{array}{c}0.956 \\
{[3.30]^{\star \star \star}}\end{array}$ & $\begin{array}{c}0.603 \\
{[3.77]^{\star * *}}\end{array}$ & $\begin{array}{c}4.258 \\
{[5.94]^{* \star \star}}\end{array}$ & $\begin{array}{l}0.119 \\
{[0.19]}\end{array}$ & $\begin{array}{c}0.907 \\
{[1.90]^{*}}\end{array}$ & $\begin{array}{c}0.910 \\
{[3.13]^{\star \star \star}}\end{array}$ & $\begin{array}{c}0.594 \\
{[3.69]^{\star \star *}}\end{array}$ \\
\hline Factor dissimilarity & $\begin{array}{l}-0.068 \\
{[0.57]}\end{array}$ & $\begin{array}{c}-0.370 \\
{[2.57]^{\star \star \star}}\end{array}$ & $\begin{array}{l}-0.206 \\
{[1.44]}\end{array}$ & $\begin{array}{c}0.374 \\
{[1.85]^{*}}\end{array}$ & $\begin{array}{l}-0.104 \\
{[0.44]}\end{array}$ & $\begin{array}{l}-0.041 \\
{[0.18]}\end{array}$ & $\begin{array}{c}-0.361 \\
{[2.50]^{\star *}}\end{array}$ & $\begin{array}{l}-0.197 \\
{[1.37]}\end{array}$ \\
\hline Human capital dissimilarity & $\begin{array}{c}-1.422 \\
{[4.37]^{\star \star \star}}\end{array}$ & $\begin{array}{c}-2.290 \\
{[6.89]^{\star \star \star}}\end{array}$ & $\begin{array}{c}-2.110 \\
{[6.46]^{\star \star \star}}\end{array}$ & $\begin{array}{c}-3.241 \\
{[4.72]^{\star \star \star}}\end{array}$ & $\begin{array}{c}-4.078 \\
{[7.18]^{\star \star \star}}\end{array}$ & $\begin{array}{c}-3.377 \\
{[5.97]^{\star \star \star}}\end{array}$ & $\begin{array}{c}-2.358 \\
{[7.12]^{\star \star \star}}\end{array}$ & $\begin{array}{c}-2.231 \\
{[6.89]^{\star \star \star}}\end{array}$ \\
\hline Transport costs & $\begin{array}{c}-0.453 \\
{[2.92]^{\star \star \star}}\end{array}$ & $\begin{array}{c}-0.469 \\
{[3.25]^{\star \star \star}}\end{array}$ & $\begin{array}{c}-0.753 \\
{[5.32]^{\star \star *}}\end{array}$ & $\begin{array}{l}0.068 \\
{[0.32]}\end{array}$ & $\begin{array}{l}-0.294 \\
{[1.35]}\end{array}$ & $\begin{array}{l}-0.241 \\
{[1.23]}\end{array}$ & $\begin{array}{c}-0.456 \\
{[3.14]^{\star \star *}}\end{array}$ & $\begin{array}{c}-0.747 \\
{[5.20]^{\star * *}}\end{array}$ \\
\hline METR $^{c}$ & $\begin{array}{c}-0.020 \\
{[2.70]^{\star * \star}}\end{array}$ & $\begin{array}{c}-0.011 \\
{[2.12]^{\star *}}\end{array}$ & $\begin{array}{c}-0.015 \\
{[3.34]^{\star * *}}\end{array}$ & & & & & \\
\hline$A E T R^{d}$ & & & & $\begin{array}{c}-0.028 \\
{[2.22]^{\star *}}\end{array}$ & $\begin{array}{l}-0.007 \\
{[0.54]}\end{array}$ & $\begin{array}{c}-0.019 \\
{[2.21]^{\star *}}\end{array}$ & & \\
\hline Corporate tax rate ${ }^{e}$ & & & & & & & $\begin{array}{l}0.012 \\
{[1.02]}\end{array}$ & $\begin{array}{l}0.002 \\
{[0.19]}\end{array}$ \\
\hline Free trade area & $\begin{array}{c}0.637 \\
{[7.99]^{* * *}}\end{array}$ & $\begin{array}{c}0.547 \\
{[7.47]^{\star * *}}\end{array}$ & $\begin{array}{c}0.536 \\
{[7.35]^{\star * *}}\end{array}$ & $\begin{array}{c}0.778 \\
{[5.12]^{* * *}}\end{array}$ & $\begin{array}{c}0.432 \\
{[2.75]^{\star * *}}\end{array}$ & $\begin{array}{c}0.759 \\
{[5.20]^{\star \star *}}\end{array}$ & $\begin{array}{c}0.573 \\
{[7.84]^{\star \star *}}\end{array}$ & $\begin{array}{c}0.565 \\
{[7.66]^{\star * *}}\end{array}$ \\
\hline FDI restrictions ${ }^{f}$ & & $\begin{array}{l}-0.039 \\
{[1.75]^{*}}\end{array}$ & $\begin{array}{l}0.008 \\
{[0.97]}\end{array}$ & & $\begin{array}{l}-0.086 \\
{[0.83]}\end{array}$ & $\begin{array}{l}0.069 \\
{[1.46]}\end{array}$ & $\begin{array}{c}-0.047 \\
{[2.05]^{\star *}}\end{array}$ & $\begin{array}{l}0.005 \\
{[0.61]}\end{array}$ \\
\hline EPL ratio ${ }^{g}$ & $\begin{array}{c}-0.044 \\
{[2.97]^{\star * *}}\end{array}$ & $\begin{array}{c}-0.032 \\
{[2.07]^{\star *}}\end{array}$ & $\begin{array}{c}-0.049 \\
{[3.29]^{\star * *}}\end{array}$ & $\begin{array}{l}0.015 \\
{[0.62]}\end{array}$ & $\begin{array}{l}-0.009 \\
{[0.30]}\end{array}$ & $\begin{array}{l}0.008 \\
{[0.28]}\end{array}$ & $\begin{array}{l}-0.029 \\
{[1.88]^{*}}\end{array}$ & $\begin{array}{c}-0.045 \\
{[3.00]^{\star * *}}\end{array}$ \\
\hline Wedge ratio ${ }^{g}$ & $\begin{array}{c}-2.598 \\
{[12.53]^{\star \star *}}\end{array}$ & $\begin{array}{c}-3.842 \\
{[14.02]^{\star \star *}}\end{array}$ & $\begin{array}{c}-3.109 \\
{[14.02]^{\star \star \star}}\end{array}$ & $\begin{array}{c}-3.828 \\
{[8.13]^{\star \star *}}\end{array}$ & $\begin{array}{c}-4.618 \\
{[9.80]^{* * *}}\end{array}$ & $\begin{array}{c}-3.767 \\
{[8.87]^{* * *}}\end{array}$ & $\begin{array}{c}-3.923 \\
{[14.29]^{\star \star *}}\end{array}$ & $\begin{array}{c}-3.180 \\
{[14.30]^{\star * *}}\end{array}$ \\
\hline Regulation ratio $^{\mathrm{h}}$ & $\begin{array}{c}-0.098 \\
{[5.73]^{\star * *}}\end{array}$ & $\begin{array}{c}-0.078 \\
{[4.50]^{\star \star *}}\end{array}$ & $\begin{array}{c}-0.081 \\
{[4.89]^{\star * *}}\end{array}$ & $\begin{array}{c}-0.074 \\
{[3.50]^{\star \star *}}\end{array}$ & $\begin{array}{c}-0.055 \\
{[2.46]^{\star \star}}\end{array}$ & $\begin{array}{c}-0.070 \\
{[2.96]^{\star * *}}\end{array}$ & $\begin{array}{c}-0.076 \\
{[4.48]^{\star \star *}}\end{array}$ & $\begin{array}{c}-0.079 \\
{[4.86]^{\star * *}}\end{array}$ \\
\hline Constant & $\begin{array}{l}0.633 \\
{[0.69]}\end{array}$ & $\begin{array}{c}-3.127 \\
{[3.95]^{\star * *}}\end{array}$ & $\begin{array}{l}8.406 \\
{[0.99]}\end{array}$ & $\begin{array}{l}1.772 \\
{[0.4]}\end{array}$ & $\begin{array}{c}-4.963 \\
{[2.53]^{\star * *}}\end{array}$ & $\begin{array}{c}-13.617 \\
{[0.52]}\end{array}$ & $\begin{array}{c}-3.462 \\
{[4.35]^{\star * *}}\end{array}$ & $\begin{array}{l}9.296 \\
{[1.10]}\end{array}$ \\
\hline Observations & 2366 & 2362 & 2349 & 1015 & 1014 & 1008 & 2362 & 2349 \\
\hline R-squared & 0.719 & 0.683 & 0.844 & 0.762 & 0.680 & 0.867 & 0.682 & 0.843 \\
\hline
\end{tabular}

a) Absolute value of t-statistics in brackets.

* significant at $5 \%$ level; ** significant at $1 \%$ level.

Period 1991-1999 for METR and 1996-1999 for AETR

b) 21 home and host countries (excluded: Czech Republic, Hungary, Iceland, Korea, Mexico, Poland and Turkey).

c) Marginal effective tax rate on FDI.

d) Average effective tax rate on FDI.

e) Statutory corporate tax rate

f) It increases with the intensity of restrictions.

g) Ratio of the EPL and labour wedge indicators in the host and home countries. The ratios increase as

EPL or the labour tax wedge in the host country becomes relatively more restrictive.

h) Ratio of indicators of lack of liberalisation in the host and home countries. The ratio increases as product market regulation in the host country becomes relatively more restrictive. 
PANEL B

\begin{tabular}{|c|c|c|c|c|c|}
\hline & \multicolumn{5}{|c|}{ Outward FDI outstock -full model } \\
\hline & \multirow{2}{*}{$\begin{array}{c}\text { TLS } \\
\text { Home }^{\text {b }} \\
\end{array}$} & \multirow{2}{*}{$\mathrm{FE}^{\mathrm{b}}$} & \multicolumn{2}{|c|}{ TLS } & \multirow{2}{*}{$\mathrm{FE}^{\mathrm{b}}$} \\
\hline & & & Home $^{b}$ & Host $^{b}$ & \\
\hline & $A$ & $B$ & $C$ & $D$ & $E$ \\
\hline Total GDP & $\begin{array}{c}5.183 \\
{[7.86]^{\star * *}}\end{array}$ & $\begin{array}{c}0.689 \\
{[2.20]^{\star *}}\end{array}$ & $\begin{array}{c}4.818 \\
{[7.16]^{* * *}}\end{array}$ & $\begin{array}{c}1.367 \\
{[2.26]^{\star *}}\end{array}$ & $\begin{array}{c}0.713 \\
{[2.27]^{\star *}}\end{array}$ \\
\hline Size similarity & $\begin{array}{c}3.025 \\
{[9.50]^{\star * *}}\end{array}$ & $\begin{array}{c}0.607 \\
{[3.80]^{\star \star *}}\end{array}$ & $\begin{array}{c}2.822 \\
{[8.69]^{\star \star \star}}\end{array}$ & $\begin{array}{c}0.923 \\
{[3.13]^{\star \star *}}\end{array}$ & $\begin{array}{c}0.614 \\
{[3.83]^{\star * *}}\end{array}$ \\
\hline Factor dissimilarity & $\begin{array}{l}-0.075 \\
{[0.63]}\end{array}$ & $\begin{array}{l}-0.207 \\
{[1.45]}\end{array}$ & $\begin{array}{l}-0.125 \\
{[1.05]}\end{array}$ & $\begin{array}{c}-0.429 \\
{[2.89]^{\star * *}}\end{array}$ & $\begin{array}{l}-0.196 \\
{[1.37]}\end{array}$ \\
\hline Human capital dissimilarity & $\begin{array}{c}-1.356 \\
{[4.20]^{* * *}}\end{array}$ & $\begin{array}{c}-2.056 \\
{[6.30]^{\star * *}}\end{array}$ & $\begin{array}{c}-1.394 \\
{[4.23]^{\star * *}}\end{array}$ & $\begin{array}{c}-2.271 \\
{[6.70]^{\star * *}}\end{array}$ & $\begin{array}{c}-2.107 \\
{[6.45]^{\star * *}}\end{array}$ \\
\hline Transport costs & $\begin{array}{c}-0.441 \\
{[2.85]^{\star \star *}}\end{array}$ & $\begin{array}{c}-0.744 \\
{[5.27]^{\star \star \star}}\end{array}$ & $\begin{array}{c}-0.449 \\
{[2.93]^{\star * *}}\end{array}$ & $\begin{array}{c}-0.443 \\
{[3.07]^{* \star *}}\end{array}$ & $\begin{array}{c}-0.754 \\
{[5.33]^{\star * *}}\end{array}$ \\
\hline METR $^{c}$ & & & $\begin{array}{c}-0.018 \\
{[2.38]^{\star \star}}\end{array}$ & $\begin{array}{l}-0.010 \\
{[1.86]^{\star}}\end{array}$ & $\begin{array}{c}-0.015 \\
{[3.24]^{* * *}}\end{array}$ \\
\hline TAX exempt*METR & $\begin{array}{c}-0.016 \\
{[-2.11]^{* *}}\end{array}$ & $\begin{array}{c}-0.017 \\
{[3.56]^{\star * *}}\end{array}$ & & & \\
\hline TAX credit*METR & $\begin{array}{c}-0.022 \\
{[2.99]^{\star \star *}}\end{array}$ & $\begin{array}{c}-0.013 \\
{[2.65]^{\star \star *}}\end{array}$ & & & \\
\hline EMTR elsewhere & & & $\begin{array}{l}0.004 \\
{[0.45]}\end{array}$ & $\begin{array}{l}0.002 \\
{[0.34]}\end{array}$ & $\begin{array}{l}0.035 \\
{[1.38\}}\end{array}$ \\
\hline Free trade area & $\begin{array}{c}0.632 \\
{[7.95]^{\star * *}}\end{array}$ & $\begin{array}{c}0.534 \\
{[7.33]^{* * *}}\end{array}$ & $\begin{array}{c}0.611 \\
{[7.43]^{\star * *}}\end{array}$ & $\begin{array}{c}0.521 \\
{[6.89]^{\star * *}}\end{array}$ & $\begin{array}{c}0.534 \\
{[7.32]^{\star * *}}\end{array}$ \\
\hline FDI restrictions $^{d}$ & & $\begin{array}{l}0.008 \\
{[0.95]}\end{array}$ & & $\begin{array}{l}-0.047 \\
{[2.07]^{\star *}}\end{array}$ & $\begin{array}{l}0.007 \\
{[0.90]}\end{array}$ \\
\hline EPL ratio ${ }^{e}$ & $\begin{array}{c}-0.044 \\
{[2.93]^{\star \star *}}\end{array}$ & $\begin{array}{c}-0.049 \\
{[3.24]^{\star \star *}}\end{array}$ & $\begin{array}{c}-0.042 \\
{[2.88]^{\star \star *}}\end{array}$ & $\begin{array}{l}-0.030 \\
{[2.00]^{* *}}\end{array}$ & $\begin{array}{c}-0.049 \\
{[3.28]^{\star * *}}\end{array}$ \\
\hline Wedge ratio $^{e}$ & $\begin{array}{c}-2.620 \\
{[12.63]^{* * *}}\end{array}$ & $\begin{array}{c}-3.139 \\
{[14.09]^{\star * *}}\end{array}$ & $\begin{array}{c}-2.596 \\
{[12.51]^{* * *}}\end{array}$ & $\begin{array}{c}-3.789 \\
{[13.94]^{\star * *}}\end{array}$ & $\begin{array}{c}-3.109 \\
{[14.00]^{\star * *}}\end{array}$ \\
\hline Regulation ratio ${ }^{f}$ & $\begin{array}{c}-0.099 \\
{[5.75]^{\star * *}}\end{array}$ & $\begin{array}{c}-0.082 \\
{[4.91]^{\star * *}}\end{array}$ & $\begin{array}{c}-0.097 \\
{[5.72]^{\star * *}}\end{array}$ & $\begin{array}{c}-0.078 \\
{[4.50]^{\star * *}}\end{array}$ & $\begin{array}{c}-0.082 \\
{[4.94]^{\star * *}}\end{array}$ \\
\hline Constant & $\begin{array}{l}0.503 \\
{[0.54]}\end{array}$ & $\begin{array}{l}8.459 \\
{[0.99]}\end{array}$ & $\begin{array}{c}0.949 \\
1.03\end{array}$ & $\begin{array}{c}-3.337 \\
{[4.17]^{\star \star *}}\end{array}$ & $\begin{array}{l}6.452 \\
{[0.75]}\end{array}$ \\
\hline $\begin{array}{l}\text { Observations } \\
\text { R-squared }\end{array}$ & $\begin{array}{l}2366 \\
0.719\end{array}$ & $\begin{array}{l}2349 \\
0.844\end{array}$ & $\begin{array}{c}2315 \\
0.7224\end{array}$ & $\begin{array}{c}2312 \\
0.6799\end{array}$ & $\begin{array}{c}2349 \\
0.8445\end{array}$ \\
\hline
\end{tabular}

a) Absolute value of t-statistics in brackets.

* significant at $5 \%$ level; ** significant at $1 \%$ level.

Period 1991-1999 for METR

b) 21 home and host countries (excluded: Czech Republic, Hungary, Iceland, Korea, Mexico, Poland and Turkey).

c) Marginal effective tax rate on FDI.

d) It increases with the intensity of restrictions.

e) Ratio of the EPL and labour wedge indicators in the host and home countries. The ratios increase as

EPL or the labour tax wedge in the host country becomes relatively more restrictive.

f) Ratio of indicators of lack of liberalisation in the host and home countries. The ratio increases as product market regulation in the host country becomes relatively more restrictive. 
Figure 3. Contributions of policy factors to the deviations in FDI ${ }^{1}$

(absolute values)

\section{Panel A. Decomposition with AETR}

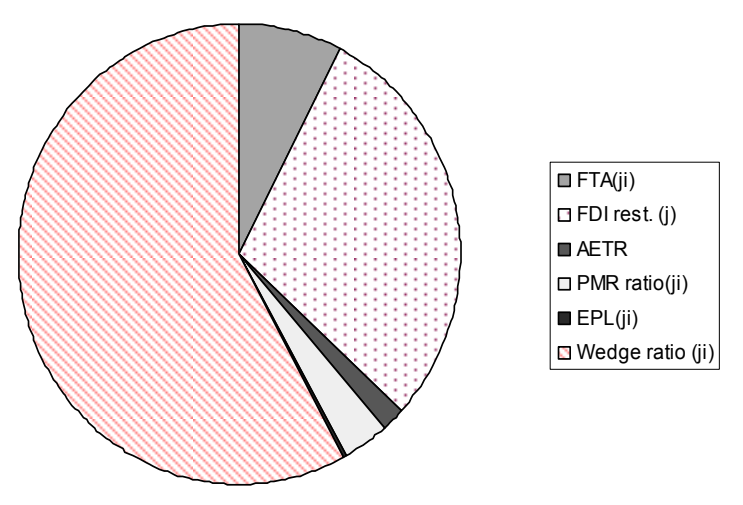

Panel B. Decomposition with METR

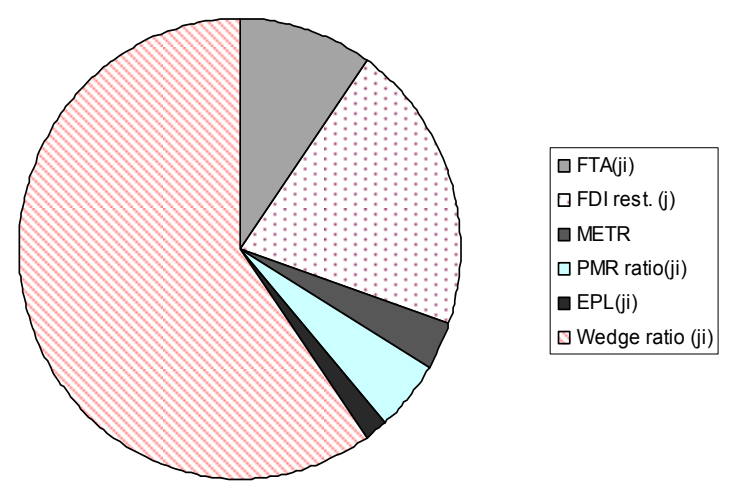

1) Figures summarise the contributions of different policies to deviations in FDI. Due to illustrative purposes, the contributions of nonpolicy related factors as well as home and host country specific effects and time effects are not shown. Contributions are based on the results of host country equations (B) and (E) in Table 6, panel $A$ and are computed taking average over the estimation the average period and investor country. 


\section{Concluding remarks}

39. There is a growing consensus that taxation matters for FDI, but the extent to which it does so has been subject to debate, and different studies produce varying tax elasticities of FDI. While these studies use a range of tax indicators, most of them concentrate exclusively on taxation ignoring the potential effect of other policies that affect the business environment in the host country where foreign affiliates operate. Empirical studies also generally ignore the possibility that bilateral FDI responds not only to home and host country tax policies and bilateral arrangements, but also to tax policies of countries that would represent valid alternatives as FDI locations for the home country MNE, because they are similar in economic structure and in other (non-tax) policies.

40. In this paper, these issues are addressed using a panel of OECD countries over the 1990s to estimate a fairly general model of bilateral FDI. The model includes new forward-looking tax indicators that subsume home and host country tax policies as well as bilateral arrangements governing the tax treatment of foreign source income. The main results, which are summarised in Table 7, can be stated very simply: focusing only on taxation in home and host countries and omitting other policies may lead to a serious overestimation of tax elasticities and their relevance for policy. The simple model including only the tax indicators shows tax elasticities and other related results (e.g., the lack of sensitivity of elasticity estimates to exemption or credit systems) that are in line with previous studies. However, when proxies are included for a range of border, product and labour market policies or for "tax diversion" of FDI to similar host countries, the results are at variance with the mainstream literature: much smaller tax elasticity estimates were found. Moreover, estimates imply that the effects of taxation on FDI are quantitatively much less relevant than the effects of other policies that contribute to make a location attractive to international investors, such as openness, labour costs and regulatory hurdles. If these results were confirmed using other kinds of data (e.g., on activity of foreign affiliates) and tax indicators (e.g., backward-looking indicators such as average tax rates), it would mean that empirical analyses that omit these factors are likely to provide a distorted picture of the response of FDI to tax policies and, by grossly overstating such response, would run the risk of misleading the policy debate. 
Table 7. Summary of estimated tax elasticities in different models

\begin{tabular}{|c|c|c|c|c|c|c|}
\hline & \multicolumn{6}{|c|}{ Basic model } \\
\hline & \multicolumn{2}{|c|}{ Home country } & \multicolumn{2}{|c|}{ Host country } & \multicolumn{2}{|c|}{$\mathrm{FE}$} \\
\hline & semi-elasticity & elasticity & semi-elasticity & elasticity & semi-elasticity & elasticity \\
\hline METR (1991-2000) & -4.600 & -1.224 & -2.667 & -0.710 & -2.190 & -0.585 \\
\hline \multirow[t]{4}{*}{ AETR (1996-2000) } & -5.716 & -1.450 & -3.628 & -0.921 & -4.198 & -1.064 \\
\hline & \multicolumn{6}{|c|}{ Basic model + EMTR else where } \\
\hline & \multicolumn{2}{|c|}{ Home country } & \multicolumn{2}{|c|}{ Host country } & \multicolumn{2}{|c|}{$\mathrm{FE}$} \\
\hline & semi-elasticity & elasticity & semi-elasticity & elasticity & semi-elasticity & elasticity \\
\hline \multirow[t]{4}{*}{ METR (1991-2000) } & -3.819 & -1.008 & -2.159 & -0.570 & -1.668 & -0.441 \\
\hline & \multicolumn{6}{|c|}{ Full model } \\
\hline & \multicolumn{2}{|c|}{ Home country } & \multicolumn{2}{|c|}{ Host country } & \multicolumn{2}{|c|}{$\mathrm{FE}$} \\
\hline & semi-elasticity & elasticity & semi-elasticity & elasticity & semi-elasticity & elasticity \\
\hline METR (1991-2000) & -1.979 & -0.527 & -1.111 & -0.296 & -1.519 & -0.405 \\
\hline AETR (1996-2000) & -2.756 & -0.977 & -0.652 & -0.231 & -1.940 & -0.490 \\
\hline
\end{tabular}




\section{BIBLIOGRAPHY}

Altshuler, R, R. and T.S. Newlon (1993), "The Effects of U.S. Tax Policy on the Income Repatriation Patterns of U.S. Multinational Corporations, in: Alberto, G., R.G. Hubbard, J. Slemrod, (eds.), Studies in international taxation, University of Chicago Press, pp. 77-115.

Altshuler, R. and H. Grubert (2003), "Repatriation Taxes, Repatriation Strategies, and Multinational Financial Policy," Journal of Public Economics 87 No. 1, pp. 73-107.

Bénassy-Quéré, A., L. Fontagne and A. Lahrèche-Révil (2003), “Tax Competition and Foreign Direct Investment", CEPII Working Paper No 2005-08.

Bénassy-Quéré, A., N. Gobalraja, and A. Trannoy (2005), “Tax and Public Input Competition, CEPII Working Paper No. 2003-17.

Clausing, K.A. (1998), “The Impact of Transfer Pricing on Intrafirm Trade”, NBER Working Paper No. 6688.

Conway, P., V. Janod and G. Nicoletti (2005), "Product Market Regulation in OECD Countries: 1998 to 2003", OECD Economics Department Working Papers, No. 419.

Conway, P. and G. Nicoletti (2006), "Product market regulation in the non-manufacturing sectors of OECD countries: measurement and highlights", OECD Economics Department Working Papers, forthcoming.

Deveureux, M.P. and H. Freeman (1995), "The Impact of Tax on Foreign Direct Investment: Empirical Evidence and the Implications for Tax Integration Scheme", International Tax and Public Finance 2.

Deveureux, M.P. and R. Griffith (1999), "The Taxation of Discrete Investment Choices", Institute for Fiscal Studies Working Paper No. W98/16.

Deveureux, M.P. and R. Griffith (2002), "The Impact of Corporate Taxation on the Location of Capital: A Review", Swedish Economic Policy Review 9, pp. 79-102.

Desai, M.A., F. Foley and J.R Hines (2002), "Chains of Ownership, Regional Tax Competition and Foreign Direct Investment”, NBER Working Paper No. 9224.

Dunning, J.H. (1977), “The Determinant of International Production”, Oxford Economic Papers, 25, pp. 289-330.

Dunning, J.H. (1981), “International Production and the Multinational Enterprise”, London, Allen and Unwin.

Erkel-Rousse, H. and D. Mirza (2002), "Import Price Elasticities: Reconsidering the Evidence", Canadian Journal of Economics Vol. 35, No. 2, pp. 282-306.

European Commission (2001), "Company Taxation in the Internal Market”, EC Staff Working Paper $\operatorname{COM}(2001) 582$. 
Ginarte, J. and W. Park (1997), “Determinants of Patent Rights: A Cross-National Study”, Research Policy, Vol. 26.

Golub, S. (2003), "Measures of Restrictions on Inward Foreign Direct Investment for OECD Countries, OECD Economics Department Working Papers, No. 357.

Gresik, T.A. (2001), “The Taxing Task of Taxing Transnationals”, Journal of Economic Literature Vol. 39, September.

Gropp, R. and K. Kostial (2000), “The Disappearing Tax Base Is Foreign Direct Investment (FDI) Eroding Corporate Income Taxes?”, IMF Working Paper No. 00/173

Grubert, H. (2004), “The Tax Burden on Direct Cross-Border Investment: Company Strategies and Government Responses", in Peter Birch Sorensen (ed.), Measuring the Tax Burden on Labour and Capital, Cambridge, Massachusetts, MIT Press (CESifo Seminar series), pp. 129-170

Grubert, H. (1998), "Taxes and the Division of Foreign Operating Income Among Royalties, Interests, Dividends and Retained Earnings", Journal of Public Economics 68.

Grubert, H. and J. Mutti (1991), "Taxes, Tariffs and Transfer Pricing in Multinational Corporate Decision Making", Review of Economics and Statistics 73/2.

Grubert, H. and J. Mutti (2000), Do Taxes Influence Where US Corporations Invest?, National Tax Journal 53, pp. 825-839.

Harris, D.G (1993), “The Impact of US Tax Law Revision on Multinational Corporations' Capital Location and Income Shifting Decisions", Journal of Accounting Research 31.

Hines, J.R. (1999), “Lessons from Behavioral Responses to International Taxation”, National Tax Journal Vol. 52/2.

Hines, J.R (1997), Tax Policy and the Activities of Multinational Corporations, in: A.J. Auerbach (ed.), Fiscal Policy: Lessons from Economic Reearch, MIT Press, Cambridge MA.

Hines, J.R and G. Hubbard (1990), "Coming Home to America: Dividend Repatriations by US Multinationals", in Taxation in the Global Economy, edited by A. Razin and J. Slemrod, Chicago: University Press.

Hines, J.R. and E.M. Rice (1994), "Fiscal Paradise: Foreign Tax Havens and American Business", Quarterly Journal of Economics 109/1.

King, M.A. and D. Fullerton (1984), "The Taxation of Income From Capital: A Comparative Study of the United States, the United Kingdom, Sweden and West Germany", University of Chicago Press.

Markusen, J.R. (2002), "Multinational Firms and the Theory of International Trade, Cambridge, MIT Press.

Mayer, T. and J.L Mucchielli (1999), "La localisation à l'étranger des entreprises multinationales. Une approche d'économie géographique hiérarchisée appliquée aux entreprises japonaises en Europe", Economie et Statistique, (326-327), pp. 159-176. 
Mooij, R.A. and S. Ederveen (2001), "Taxation and Foreign Direct Investment", CPB (Netherlands Bureau for Economic Policy Analysis) Discussion Paper No. 3.

Mooij, R.A. and S. Ederveen (2005), "Explaining the Variation in Empirical Estimates of Tax Elasticities of Foreign Direct Investment", Tinbergen Institute Discussion Paper, TI 2005-108/3.

Nicoletti, G, S. Golub, D. Hajkova, D. Mirza, and K.-Y. Yoo, (2003), "Policies and International Integration: Influences on Trade and Foreign Direct Investment, OECD Economics Department Working Papers, No. 359.

Nicoletti, G., S. Scarpetta and O. Boylaud (1999), "Summary Indicators of Product Market Regulation with an Extension to Employment Protection Legislation", OECD Economics Department Working Papers, No. 226.

OECD (1991), “Taxing Profits in a Global Economy”.

OECD (2004), “OECD Employment Outlook”.

OECD (2007), “Taxation and Foreign Direct Investment”, OECD Tax Policy Studies series, forthcoming.

Rousslang, D.J. (1997), "International Income Shifting by US Multinational Corporations”, Applied Econometrics 29.

Slemrod, J. (1990), "Tax Effects on Foreign Direct investment in the United States: Evidence From a Cross-Country Comparison", in Taxation in the Global Economy, edited by A. Razin and J. Slemrod, Chicago, University of Chicago Press.

Tanzi, V. and A.L. Bovenberg (1990), "Is There A Need For Harmonizing Capital Income Taxes Within EC Countries?, in H. Siebert (ed.), Reforming Capital Income Taxation, Tubingen: Mohr.

Weichenrieder, A. (1996), "Fighting International Tax Avoidance: The Case of Germany", Fiscal Studies 17.

Yoo, K.-Y. (2003), “Corporate Taxation of Foreign Direct Investment Income 1991-2001”, OECD Economics Department Working Papers, No. 365. 
$\mathrm{ECO} / \mathrm{WKP}(2006) 30$

\section{WORKING PAPERS}

The full series of Economics Department Working Papers can be consulted at www.oecd.org/eco/Working_Papers/

503. Wage setting in Finland: Increasing flexibility in centralised wage agreements (July 2006) Åsa Johansson

502. Taxation, Business Environment and FDI Location in OECD Countries (July 2006) Dana Hajkova, Giuseppe Nicoletti, Laura Vartia and Kwang-Yeol Yoo

501. The political economy of structural reform: Empirical evidence from OECD countries (July 2006) Jens Høj, Vincenzo Galasso, Giuseppe Nicoletti and Thai Thanh Dang

500. Labour market performance, income inequality and poverty in OECD countries (July 2006) Jean-Marc Burniaux, Flavio Padrini and Nicola Brandt

499. Improving Public-Spending Efficiency in Czech Regions and Municipalities (July 2006) Philip Hemmings

498. Policies to Promote Innovation in the Czech Republic (July 2006) Alessandro Goglio

497. Getting Education Right for Long-Term Growth in the Czech Republic (July 2006) Alessandro Goglio

496. Assessing the 2005 Czech Proposals for Pension Reform (July 2006) Philip Hemmings and Edward Whitehouse

495. Poland's Education and Training: Boosting and Adapting Human Capital (July 2006) Paul O’Brien and Wojciech Paczynski

494. The Rates and Revenue of Bank Transaction Taxes (July 2006) Jorge Baca-Campodónico, Luiz de Mello and Andrei Kirilenko

493. Nothing Ventured, Nothing Gained: The Long-Run Fiscal Reward of Structural Reforms (July 2006) Peter Hoeller and Claude Giorno

492. Ireland's Housing Boom: What has Driven It and Have Prices Overshot? (June 2006) Dave Rae and Paul van den Noord

491. Boosting Competition in Ireland (June 2006) Dave Rae, Line Vogt and Michael Wise

490. Factors Behind Low Long-Term Interest Rates (June 2006) Rudiger Ahrend, Pietro Catte and Robert Price

489. The Fiscal Challenge in Portugal (June 2006) Stéphanie Guichard and Willi Leibfritz

488. Are House Prices Nearing a Peak? A Probit Analysis for 17 OECD Countries (June 2006) Paul van den Noord

487. Maintaining Switzerland's Top Innovation Capacity (June 2006) Florence Jaumotte 
486. Employment Patterns in OECD Countries: Reassessing the Role of Policies and Institutions (June 2006) Andrea Bassanini and Romain Duval

485. Brazil's Fiscal Stance During 1995-2005: The Effect of Indebtedness on Fiscal Policy Over the Business Cycle (May 2006) Luiz de Mello and Diego Moccero

484. Realising the Oil Supply Potential of the CIS: The Impact of Institutions and Policies (May 2006) Rudiger Ahrend and William Tompson

483. Summary of a workshop on global convergence scenarios: structural and policy issues (May 2006) Nick Vanston

482. Revised OECD methods for supply-side and medium-term assessment: a capital services approach (July) Pierre-Olivier Beffy, Patrice Ollivaud, Pete Richardson and Frank Sédillot

481. Balancing health care quality and cost containment: the case of Norway (February 2006) Alexandra Bibbee and Flavio Padrini

480. The ageing challenge in Norway: ensuring a sustainable pension and welfare system (February 2006) Benoît Bellone and Alexandra Bibbee

479. Strengthening innovation in the Netherlands: Making better use of knowledge creation in innovation activities (February 2006) David Carey, Ekkehard Ernst, Rebecca Oyomopito and Jelte Theisens

478. How to sustain growth in a resource based economy? The main concepts and their application to the Russian case (February 2006) Rudiger Ahrend

477. Projecting OECD health and long-term care expenditures: What are the main drivers? (February 2006)

476. Alternative measures of well-being (January 2006) Romina Boarini, Åsa Johansson and Marco Mira D'Ercole

475. Recent house price developments: the role of fundamentals (January 2006) Nathalie Girouard, Mike Kennedy, Paul van den Noord and Christophe André

474. Reforming federal fiscal relations in Austria (January 2006) Andrès Fuentes, Eckhard Wurzel and Andreas Wörgötter

473. Product market competition and economic performance in France Concurrence sur les marchés de produits et performance économique en France (January 2006) Jens Høj and Michael Wise

472. Product market reforms and employment in OECD countries (December 2005) Giuseppe Nicoletti and Stefano Scarpetta

471. Fast-falling barriers and growing concentration: the emergence of a private economy in China (December 2005) Sean Dougherty and Richard Herd

470. Sustaining high growth through innovation: reforming the $R \& D$ and education systems in Korea (December 2005) Yongchun Baek and Randall Jones

469. The labour market in Korea: enhancing flexibility and raising participation (December 2005) Randall Jones 